How soon succeeding eyes begin to look, not read. ${ }^{1}$

Philip Larkin's poem 'An Arundel Tomb', published in his 1964 collection The Whitsun Weddings, is a meditation on the medieval tomb of an earl and countess of Arundel in Chichester Cathedral (ftg. 1). An encounter with this monument prompts the poet to ruminate on the transformations it has undergone during the six centuries that have passed since the tomb was erected. The changes he describes do not concern the physical appearance of the sculpture, but rather the ways in which successive generations of visitors - whom he terms 'the endless altered people' - have responded to the monument, especially the shifting emphasis on text and image. According to Larkin, modern visitors tend to look ftrst and read later (if at all), whereas in the Middle Ages the sculpted effigies were seen as a mere visual flourish, 'thrown off in helping to prolong/ The Latin names around the base'. ${ }^{2}$ There is, however, a previously unnoticed irony in Larkin's poem. The tomb on which the poem is based does not actually have an epitaph: the limestone chest was heavily restored in the nineteenth century and all records of a medieval epitaph - if there ever was one - have been lost. ${ }^{3}$ Larkin, a craftsman of the written word, invented a sculpted epitaph as a counterpart to the sculpted ftgures.

'An Arundel Tomb' encapsulates some of the complexities surrounding the study of sculpture and the epitaph. This is a subject that touches upon issues central to the history of art: the relationship between word and image, text and representation; the role of objects in remembering the past; the problem of accessing the experience of the 'viewer'. A flurry of books and articles over the last twenty years have explicitly sought to treat the inscribed word as artwork, drawing attention to the visual and material qualities of inscriptions as replete with meanings which supplement and sometimes even contradict the messages conveyed by the words themselves. ${ }^{4}$ However, studies of the epitaph continue to be characterized by a bifurcated approach: historians and art historians tend to use epitaphs primarily as sources of information on the biography of the deceased, their date of death, political and familial connections, and devotional preferences, whereas literary scholars pay close attention to the linguistic and literary qualities of the epitaph but extract the words from their material context. ${ }^{5}$ One exception is Amando Petrucci's Writing the Dead. Death and Writing Strategies in the Western Tradition, which charts the history of the epitaph - sculpted and literary - in the Western 
1. Monument to a Fitzalan knight and lady, c. 1375-c. 1397, limestone, length: $208 \mathrm{~cm}$, height: $94 \mathrm{~cm}$, width: $117 \mathrm{~cm}$. (photo: author) North aisle, Chichester Cathedral

tradition, from prehistory to the present. ${ }^{6}$ Petrucci argues that the changing status of the sculpted epitaph reflects Western society's fluctuating attitudes to the relationship between the written word, image and identity. Through an examination of the positioning, size, script and linguistic qualities of sculpted epitaphs, he claims that the importance placed on commemorative text - as opposed to commemorative image - has swung back and forth over time like a pendulum, the high points for the inscribed word coming in the Classical, late antique and Renaissance periods, and the low points in the Middle Ages and modern era. In contrast to Larkin's suggestion that 'Latin names' were the central feature of funerary sculpture in the Middle Ages, Petrucci characterizes the medieval epitaph as a mere appendage to the sculpted images, its legibility of lesser importance than the messages conveyed by the iconographic scheme. According to Petrucci, during the Middle Ages the sculpted epitaph was transformed from a 'monument', a memorial to the deceased in itself, to a 'document', its function limited to authenticating the sculpted images. ${ }^{7}$

A far more intimate and complex relationship between text and image characterizes the epitaph of João I (1358-1433), King of Portugal, and his English wife, Philippa of Lancaster (1360-1415), inscribed on the north and south sides of their monument at the Dominican convent of Santa Maria de Vitória in Batalha (Portugal) (ftgs. 2-5). The chronology of the events recounted in the two epitaphs makes it clear that they are intended to be read as a single text, starting with Philippa's and ending with João's. In this 'Sources and Documents' section, the Latin inscription has been fully transcribed and translated into English for the ftrst time, accompanied by a comprehensive photographic record. ${ }^{8}$ This extensive epitaph has been almost entirely overlooked by modern scholars. Studies of the monument to João and Philippa tend to focus on their effigies, particularly the ftnely carved face of the king as an early instance of portraiture, while the majority of published photographs capture the two ftgures from above, obscuring the inscribed text. ${ }^{9}$ Yet when viewed in situ, the inscription is the most prominent feature of the tomb; sculpted words, not sculpted bodies, are the abiding impression of the memorial. This is by far the longest epitaph on a medieval tomb in western Europe, comprising just fewer than 1,700 words. It is unique in the richness of its historical content, visual

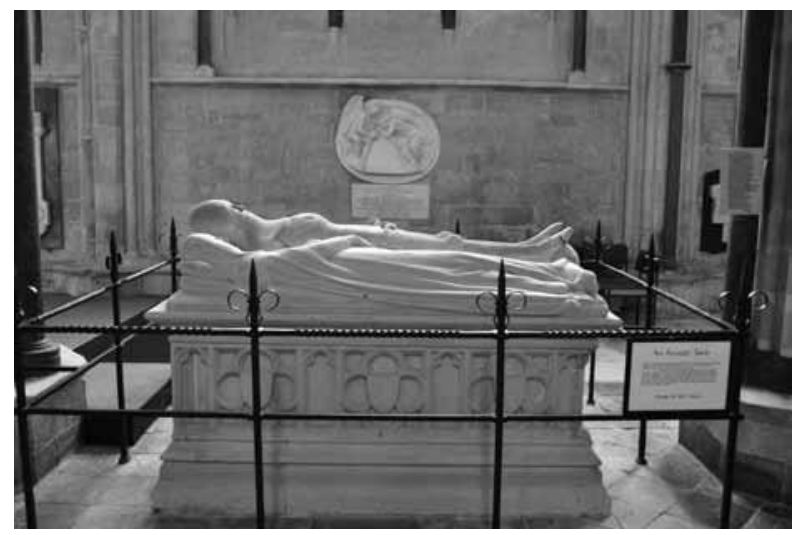
prominence and exquisitely ornate appearance. But it is more than a mere curiosity. The epitaph at Batalha raises important questions about the status and function of inscriptions during the ftfteenth century, a period during which attitudes towards the written word - and its sculpted manifestations - were undergoing a radical transformation in western Europe. At the same time, it challenges art historians to rethink their approach to text and image in memorial sculpture.

Most inscriptions on medieval tombs are 
2. Monument to João I and

Philippa of Lancaster, c. 1426-34 limestone, length of tomb chest:

$334 \mathrm{~cm}$, height of tomb chest

(including stone base): c. 198 $\mathrm{cm}$, width of tomb chest: 170 $\mathrm{cm}$, length of João's effigy: 178 $\mathrm{cm}$, length of Philippa's effigy: $169 \mathrm{~cm}$, height of letters: c. $2 \mathrm{~cm}$. Founder's Chapel, monastery of Santa Maria de Vitória, Batalha (photo: author)

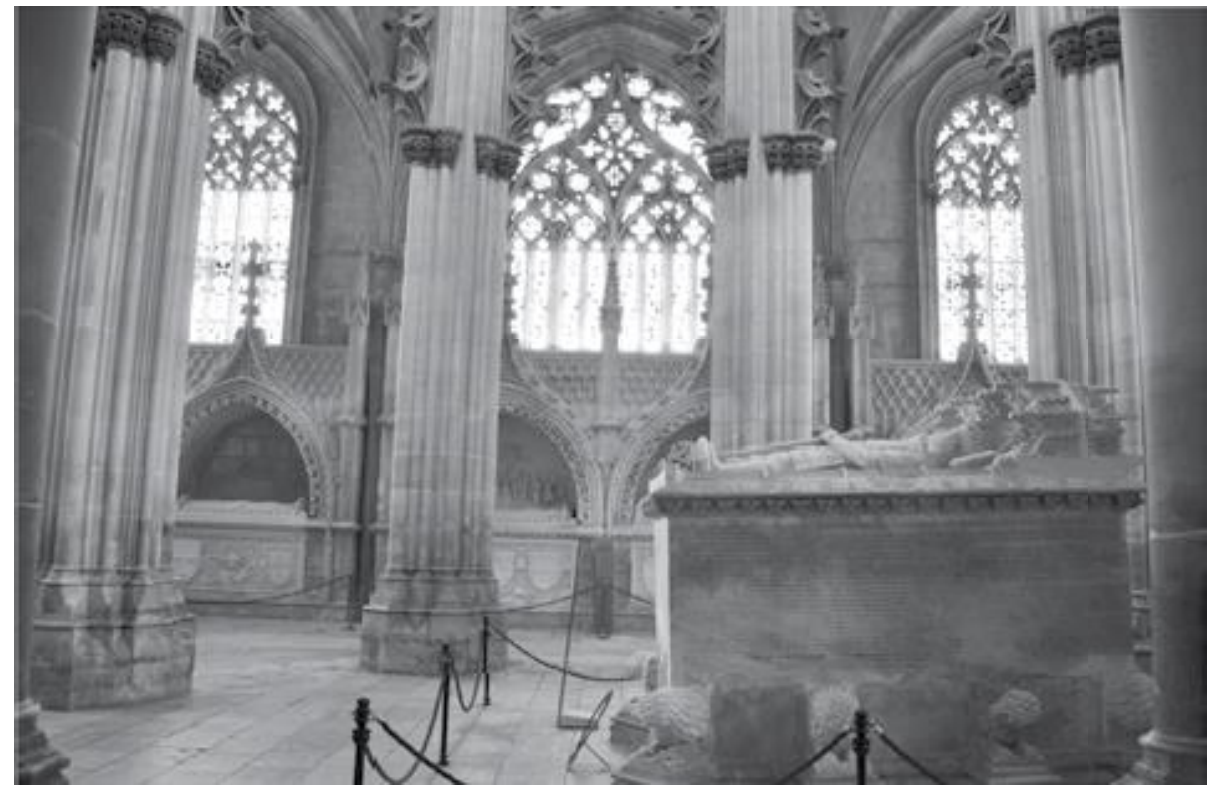

primarily concerned with prompting the viewer to pray for the soul of the deceased in order to lessen their time in Purgatory. They contain only the biographical information necessary to this end: the deceased's name and date of death. ${ }^{10}$ Although the epitaphs to João and Philippa both end with a short prayer (the king's epitaph also starts with one), the majority of the text is a record of the royal couple's virtues and accomplishments. João is presented as a model Christian warrior, complementing the decision - unprecedented in Portugal - to depict the king in armour and holding the baton of command. ${ }^{11}$ The military emphasis is also reflected in the location of the monument within the Dominican convent of Batalha, a religious institution founded by João after he won the throne of Portugal in battle against the King of Castile at Aljubarrotta in $1385 .{ }^{12}$ The epitaph presents the victory at Aljubarrotta as divinely ordained, while João's conquest of the city of Ceuta in 1415 is celebrated as a crusade against the Muslims, the king being described as 'inflamed with the fervour of faith'. ${ }^{13}$ This is a narrative carefully constructed to aggrandize a king who had been born a bastard and whose tenuous claim to the throne rested entirely upon his victories on the battlefteld. João's own role is emphasized by omitting that of others, most notably his brilliant strategist Nuno' Alvares Pereira. ${ }^{14}$ The miraculous nature of João's two victories is stressed by linking both events to the same date, the vigil of the Assumption of the Virgin Mary on 14 August, the day on which the king is also said to have died..$^{15}$

Whereas such retrospective legitimation was standard within the rhetoric of medieval kingship, the extent to which the moral authority of the new dynasty was projected on to the person of the queen is more unusual. After opening with a genealogy describing the various lines of Philippa's connection to the English throne, the ftrst half of the queen's epitaph narrates how her father, John of Gaunt, sailed to Iberia to claim the throne of Castile and thereby formed an alliance with João, which Gaunt sealed by offering 


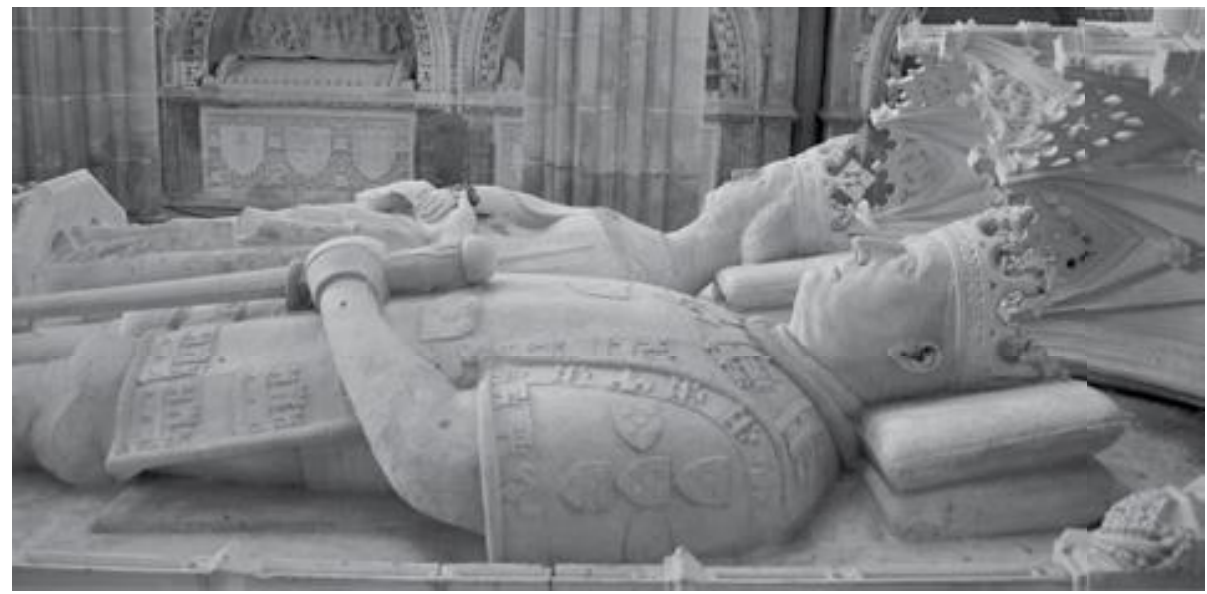

the hand of Philippa in marriage. The epitaph then shifts its focus to the queen herself. It is a remarkable portrait of the ftfteenth-century feminine ideal: Philippa is presented as a devout Christian, spending almost all her time in contemplation, reading or prayer, an image reinforced by the Book of Hours which the effigy holds in her left hand. ${ }^{16}$ Yet, according to the epitaph, even Philippa's devotion to God was surpassed by her perfect love for her husband and children: the queen is described as 'an exemplar of good living for married women, a guiding direction for her ladies in waiting, and the occasion of absolute honour' ${ }^{17}$ Again, this portrayal is communicated through both text and image, suggesting that the designer of the tomb and the composer of the epitaph worked closely in collaboration, or else were one and the same person. Philippa's effigy is depicted holding her husband's hand, while the chamfer of the tomb chest on the south, west and east sides bears the repeated motto in large Gothic lettering: 'ye me plet' [I love him]. ${ }^{18}$ There is even the suggestion that Philippa had attained the status of a saint. The epitaph states that on the exhumation of the queen in 1416, her body was discovered to be 'intact and pleasantly sweet-smelling' - a standard formula for claiming sainthood - followed by a list of named witnesses to the miraculous state of the corpse. ${ }^{19}$

One of the epitaph's most striking and unusual features is its meticulous description of the fate of João and Philippa's bodies after death. The queen's epitaph details her initial burial in the nuns' choir of the female Cistercian monastery of Odivelas in Coimbra on 19 July 1415, the subsequent exhumation of her body on 9 October 1416, its procession and reburial in the 'major and principal chapel' of Batalha on 15 October $1416,{ }^{20}$ and the ftnal exhumation of the queen and her reburial in the Founder's Chapel on 14 August $1434 .{ }^{21}$ João's epitaph describes the translation of his body from Lisbon to be interred alongside Philippa at Batalha on 30 November 1433, and repeats the account in Philippa's epitaph (with added details) of the translation and reburial of the royal couple on 14 August $1434 .{ }^{22}$ This extended description of burials, exhumations and reburials takes up almost a third of the inscription. Even the names and titles of the members of the royal family who were present at the various funeral processions are recorded, painstakingly listed in order 
4. The south face of the tomb chest (photo: author)

5. The north face of the tomb chest (photo: author) of precedence. When read in tandem with the accounts of their funerals in the epitaph, the sculpted bodies of João and Philippa take on a new potency as proxies for the natural bodies of the royal couple, a visual reminder of the bones (and in Philippa's case sweet-smelling flesh) lying beneath the tomb..$^{23}$ The penultimate sentence of Phillipa's epitaph - referring to the translation of the royal couple to the Founder's Chapel - notes that the queen's body was buried next to that of her husband, 'beneath that form which is enclosed/ preserved within his epitaph' ${ }^{24}$ This seems to be a prompt for the viewer to walk to the north side of the memorial, where João's effigy lies atop his epitaph on the tomb chest, which in turn is situated immediately above the vault where his corpse was laid to rest. Indeed, the epitaph continually emphasizes that the events it describes occurred in the very same place where it stands. The text refers to the fact that the bodies were processed to 'this' chapel and that the king and queen were buried in 'this' tomb. ${ }^{25}$ By presenting this ftnal burial as the apogee of the royal bodies' long iterations, the epitaph aggrandizes the Founder's Chapel, reshaping the viewer's perception of the space in which they are standing. The inscription becomes a mnemonic prompt, encouraging the viewer to remember - or imagine - the elaborate funerary rituals for the king and queen as they gaze upon the monument that acted as the enduring culmination of these performances.

The length and complexity of this inscription places it in a different realm from the kind of epitaphs typically carved on funerary monuments, instead suggesting parallels with literary works, such as biographies and funerary panegyrics. In digesting the lineage and deeds of the royal couple, as well as offering a psychological portrait of the deceased, the epitaph at Batalha is closely comparable to semblanzas, the literary portraits of great men and women sometimes incorporated into historical and genealogical works from late medieval Castile, Aragón and Portugal, the most famous example being Fernan Pérez de Guzmán's Generaciones y semblanzas (completed c. 1450-55). ${ }^{26}$ By the ftfteenth century, semblanzas had adopted an increasingly panegyric tone: they typically began with the name of the person portrayed and a dignifying attribute, followed by a section on their lineage, their bodily and moral characteristics, and an obit detailing their age at death and the place
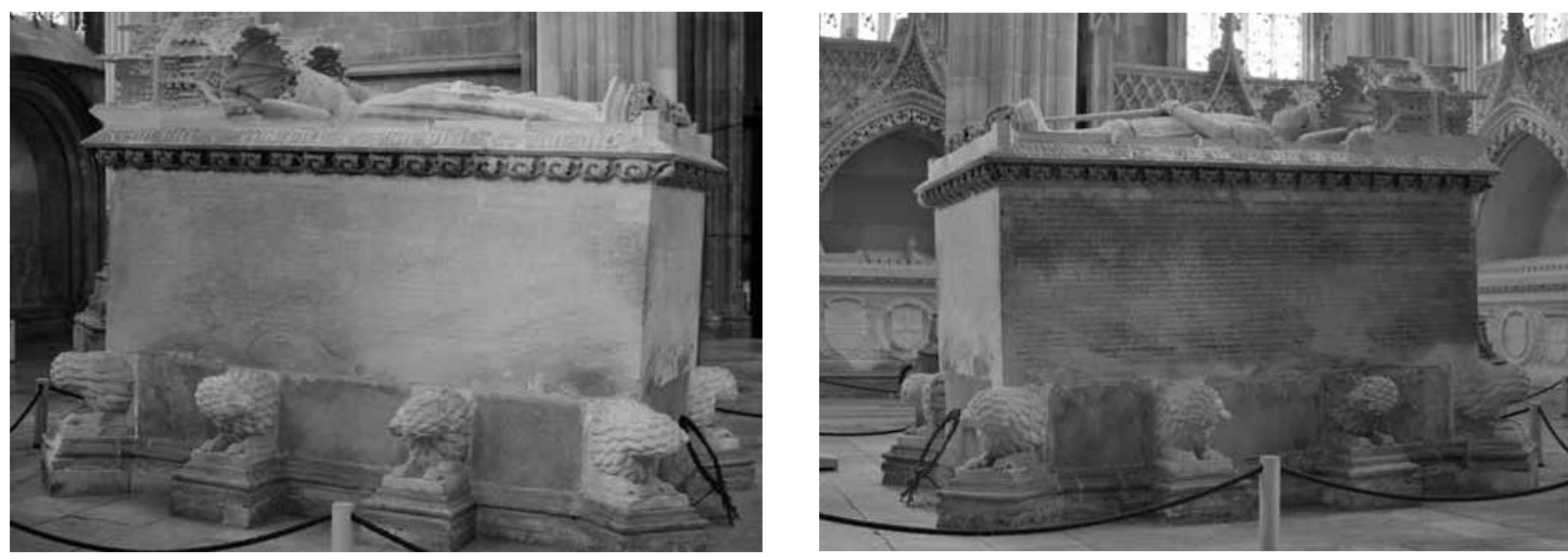
6. Monument to Richard II and Anne of Bohemia, 1395-99, gilt cast copper-alloy, Purbeck marble, length: $367 \mathrm{~cm}$, height (from the pavement of the Confessor's Chapel): $145 \mathrm{~cm}$, width: $189 \mathrm{~cm}$. Confessor's Chapel, Westminster Abbey, London

(photo: (C) Courtauld Institute of Art)

where they died. ${ }^{27}$ The epitaphs to João and Philippa conform to this structure, although each section is expanded and supplemented with narrative sequences chronicling the military exploits of João and John of Gaunt. ${ }^{28}$ The only feature customarily included in semblanzas but missing from the epitaph at Batalha is a description of the king and queen's physical appearance; perhaps the composer of the epitaph thought this to be unnecessary given the sculpted effigies lying directly above the inscribed text. Robert Folger, a specialist in ftfteenth-century Iberian historiography, has emphasized the importance of semblanzas in royal commemoration, arguing that these literary portraits acted as a blueprint for the formation of mnemonic images of dead kings, thus creating a 'temporally and spatially dispersed memorial community of readers'.$^{29} \mathrm{He}$ highlights the way in which certain semblanzas, such as those in the late fourteenth-century chronicles of Pedro López de Ayala, devote as much attention to the subject's death as they do their life, including the person's precise date of death, age at time of death, a description of their funeral, devotional formulae and even the location of their burial. ${ }^{30}$ Semblanzas could therefore be understood as prompts for the reader to meditate on the tombs of the illustrious dead, thereby encouraging prayer for their souls. At Batalha, this connection between literary and monumental commemoration takes on material form; the literary portrait is carved directly on to the tomb chest, meaning that the reader is required to visit the monument before they can read the semblanzas of the king and queen.

There are particularly close correspondences between the epitaph to João and Philippa and the near-contemporary Crónica de D. João I by Fernão Lopes, commissioned by João's eldest son and heir, Duarte. ${ }^{31} \mathrm{~A}$ section on Philippa's habits and moral virtues in the epitaph (lines 40-62 [41-65]) is almost identical to the semblanza of the queen in chapter XCVIII of the chronicle: both comment on Philippa's extensive knowledge of the divine liturgy, her extraordinary dedication to reading and prayer, her generosity in almsgiving,

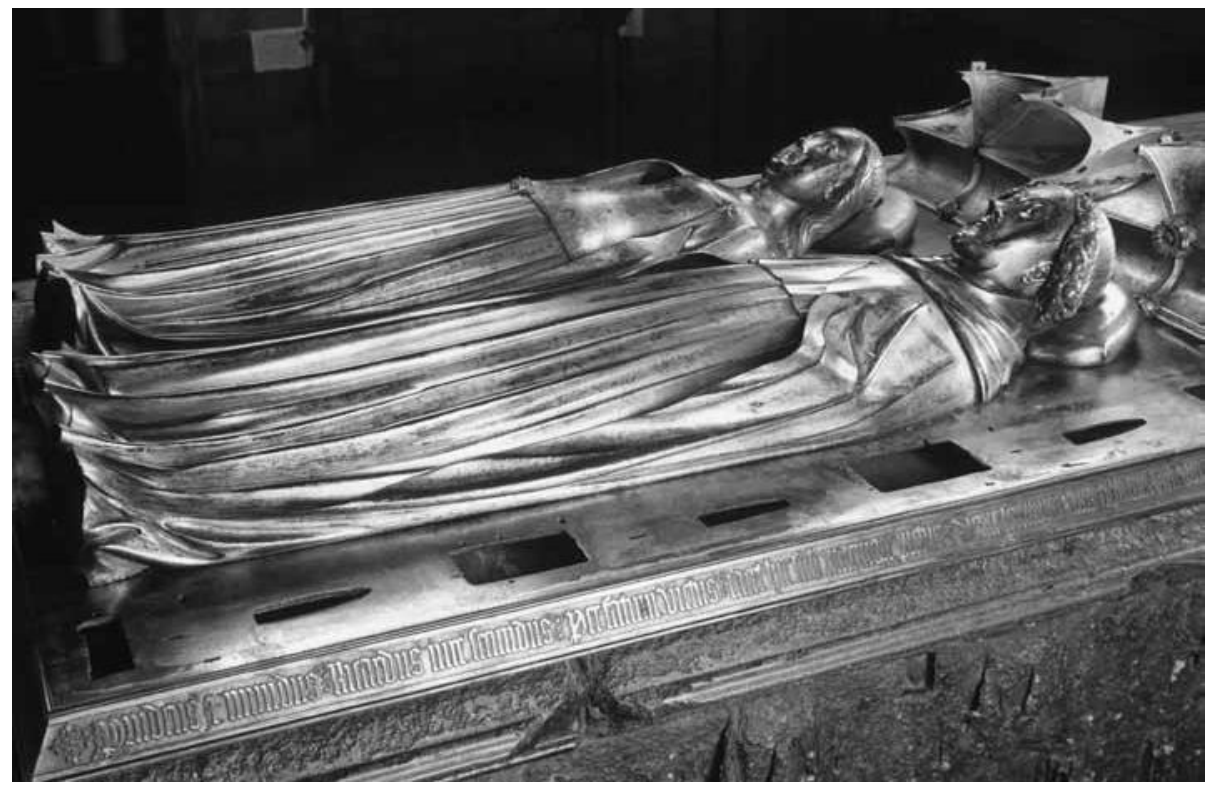




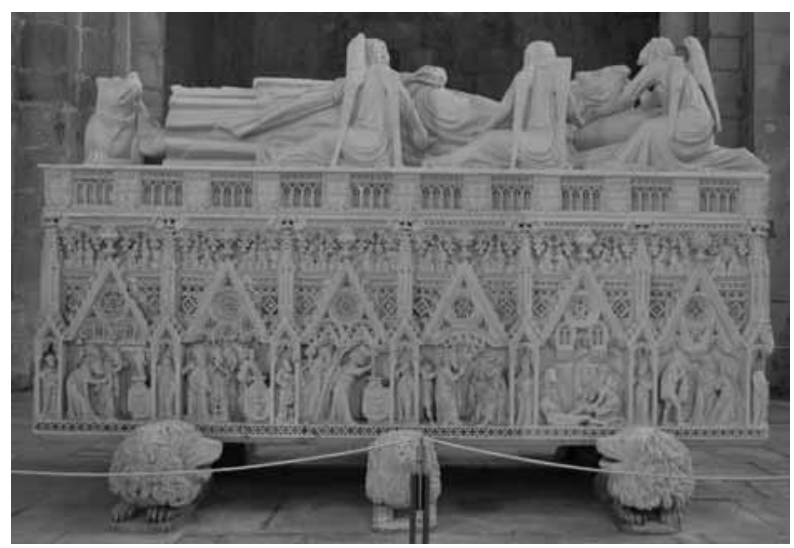

her exemplary love for her husband and her dedication to the instruction and education of her children. ${ }^{32}$ Duarte was undoubtedly the patron of the epitaph as well as the chronicle: the inscription refers to Duarte's reign in the present tense and describes the new king as 'manfully imitating his father's deeds' ${ }^{33}$ One explanation for the close relationship between inscription and chronicle could be that Duarte ordered Lopes - his royal chronicler and keeper of the royal archives - to compose the epitaph on the tomb of his parents. ${ }^{34}$ On the other hand, given that Lopes is known

7. Monument to Pedro I, 1361-67, limestone, length: $325 \mathrm{~cm}$, height: $120 \mathrm{~cm}$, width: $122 \mathrm{~cm}$. Monastery of Santa Maria, Alcobaça (photo: author) to have used epitaphs as sources for his chronicles, a more likely scenario would be for the chronicler to have copied the description of Philippa from her memorial and then used this material to compose the semblanza. ${ }^{35}$ If this were the case, it would provide evidence for the transmission of the epitaph soon after it was inscribed, as well as suggesting that it was understood by contemporaries as an authoritative biographical text.

The novelty of the epitaph at Batalha thus lies in its material rather than its literary qualities: a form of epitaph typically presented on parchment is instead inscribed directly on to the tomb chest, fused on to the surface of the stone. In the later Middle Ages it was not uncommon for longer texts, describing notable features within the building, listing royal associations or referencing indulgences associated with the site, to be written on parchment leaves pasted to wooden boards and then exhibited within the church. ${ }^{36}$ These parchment tablets were also used to display epitaphs, such as the three lengthy Latin verse eulogies to Anne of Bohemia (1366-94) which hung close to the tomb commemorating herself and her husband, Richard II (1367-1400), King of England and Philippa's ftrst cousin, in the Confessor's Chapel at Westminster Abbey. ${ }^{37}$ Transcribed by an anonymous Bohemian traveller in the early ftfteenth century, the epitaphs were almost certainly erected some time between the queen's death in 1395 [AQ] and the completion of her tomb in $1399 .{ }^{38}$ The close proximity of monument and parchment meant that the sculptural portrayal of Anne as a beautiful maiden with long, flowing hair could be supplemented with verses lauding the dead queen as a 'flower of the fteld' and 'pious consort' whose flesh was impervious to decay (ftg. 6). ${ }^{39}$ At the same time, the portability of the parchment epitaphs meant that the tomb chest itself was left free for the display of enamelled heraldic shields and gilt-bronze saints; the only permanent inscription on Richard and Anne's monument is a cast bronze ftllet framing the effigies on the chamfer of the tomb chest, the positioning of which means that less than half of the Latin text is visible. ${ }^{40}$ Since João and Philippa seem to have used Richard and Anne's memorial as a model for the tomb of their ftrst-born son, Afonso (d. 1400), it is surprising that their own monument at Batalha expresses such a radically different approach to the relative importance of text and image. ${ }^{41}$ Its design also sits in stark contrast to the memorials commemorating João's 


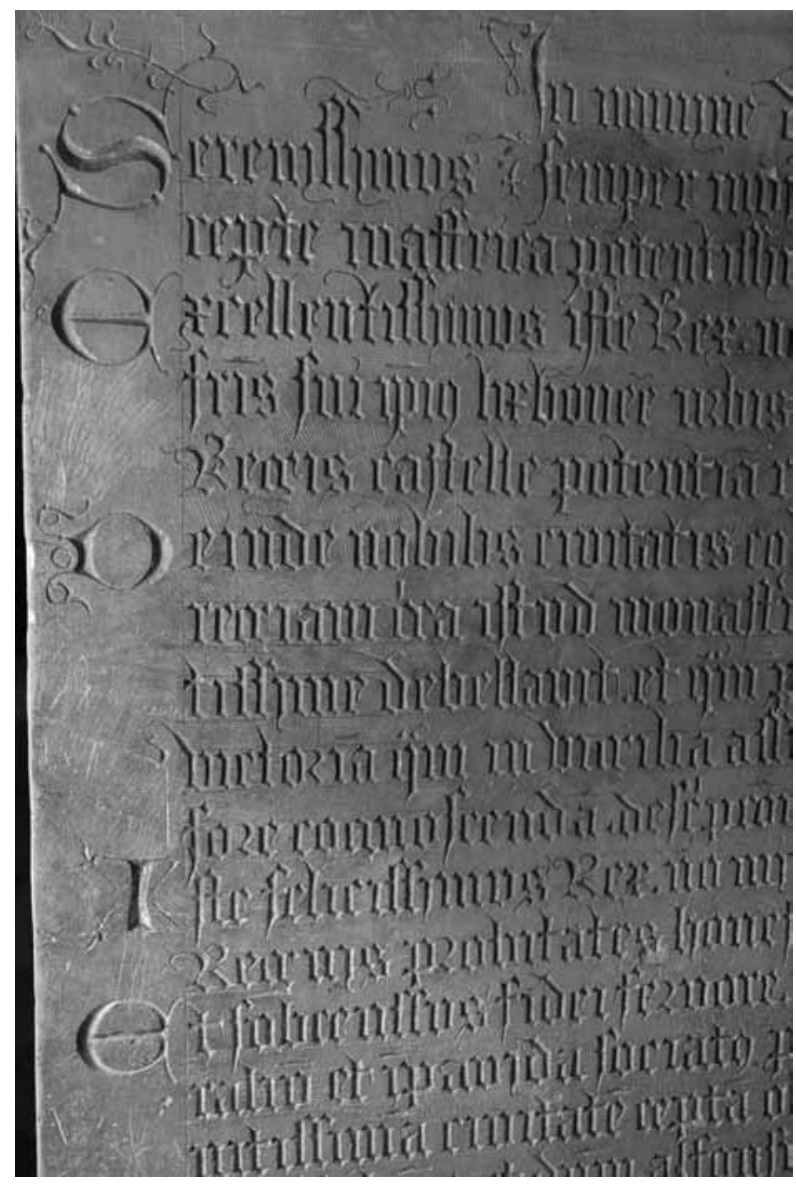

father, Pedro I (1320-67) and his consort Inês de Castro (1325-48/49) at the Cistercian monastery of Alcobaça, monuments which entirely lack inscriptions, their limestone tomb chests instead carved with scenes of the life of St Bartholomew and the life of Christ housed in intricate micro-architectural frames (ftg. 7). ${ }^{42}$ At Batalha, the epitaph is an integral and permanent feature of the monument, displacing the imagery typically found on the tomb chest: the display of the sculpted word is prioritized over the display of sculpted image.

The appearance of the inscription reinforces the impression of a literary work transposed on to stone. Each panel of stone has been incised with a margin and lines for the letters, in the same way that parchment folios were ruled with a blunt instrument before the scribe began the text (ftg. 8). While these lines had a practical function in setting out the lengthy inscription, it would have been easier and quicker to render them in slate or chalk, to be erased when the monument was completed; the fact that the margin and lines were carved permanently into the stone suggests that the two long sides of the chest were intended to mimic the appearance

8. Detail of the epitaph to João, north face of the tomb chest (photo: author) of parchment. This impression is heightened through the treatment of the inscribed text. The epitaph is rendered in an ornate Gothic textualis script, a form of lettering common to both inscriptions and manuscripts in ftfteenthcentury Portugal. ${ }^{43}$ Remnants of paint survive on the north side of the tomb chest, revealing that the letters and ruled lines were originally ftlled with red paint, resembling rubricated text. ${ }^{44}$ The inscription features decorative line ftllers, large ornamental capitals to mark new sections of the text and (in the case of the inscription below João's effigy) a heading, embellishments associated with the most luxurious products of ftfteenth-century scriptoria (ftgs. 9-12). The size and shape of the text block - much wider than it is long - prompts comparisons with one textual object in particular: the charter (compare ftgs. 5 and 13). Recording various legal settlements, such as the exchange of property, settlement of a dispute or bestowal of offices and rights, these short documents were authenticated by a wax seal that would often bear the likeness and insignia of the issuing authority. ${ }^{45} \mathrm{~A}$ parallel between tombs and charters is suggested by Julian Luxford in his article 'Tombs as Forensic Evidence', which draws together a wide range of material (including records of legal disputes, monumental inscriptions and the illustrations of the Anlaby cartulary) to show that tombs were seen to possess particular value as legal evidence in late medieval English society. ${ }^{46}$ If the epitaph at Batalha is understood as a type of charter, then the sculpted ftgures and 
9. Decorated initials, detail of the epitaph to João, north face of the tomb chest (photo: author)

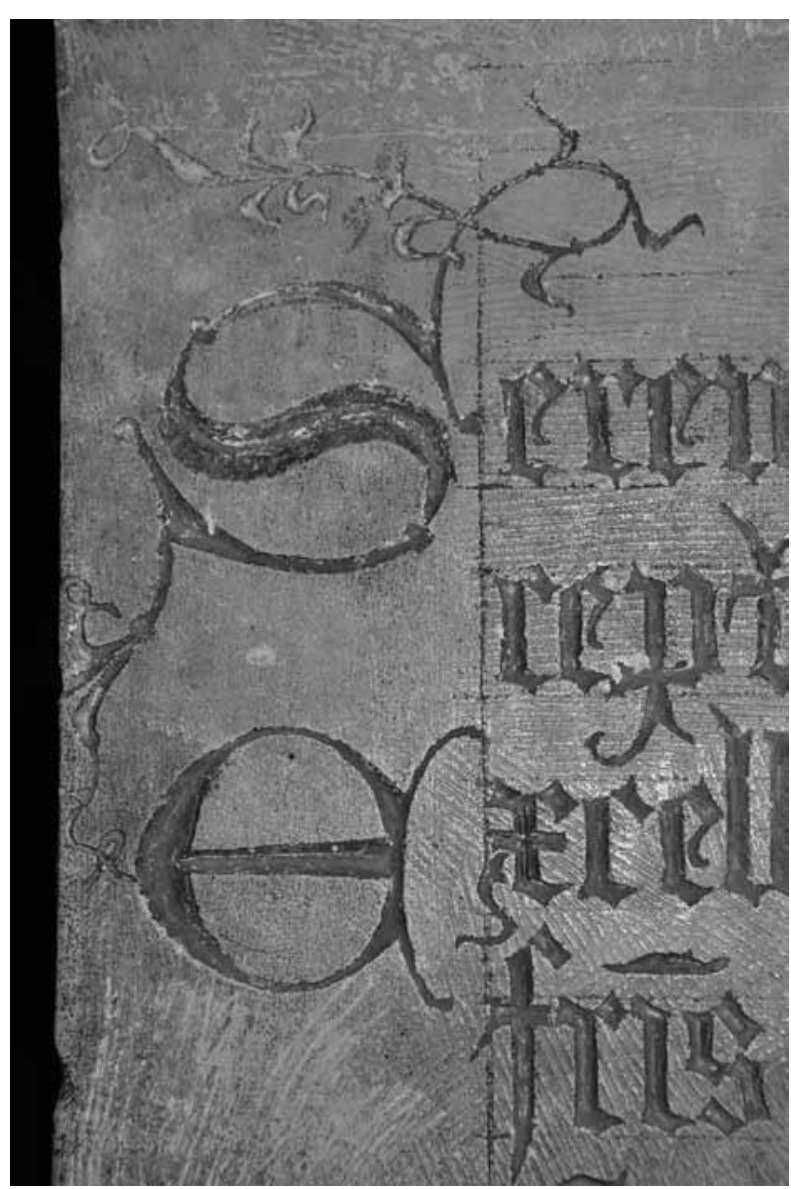

heraldic decoration could be seen to take on the role of a seal. Since the primary function of the imagery on a seal lies in its authenticating presence, rather than the messages communicated by its iconographic scheme, this reorientates our understanding of the relationship between epitaph and sculpted ftgures. Whereas Petrucci characterized medieval epitaphs as documentary appendages to the sculpted ftgures, at Batalha this relationship works in the opposite direction. ${ }^{47}$ The 'document' is monumentalized, and the monument becomes a document: by echoing the appearance of a medieval charter the epitaph proclaims its authority, while the effigies authenticate the textual descriptions of the king and queen.

There is one point at which the epitaph becomes explicitly self-referential. Recounting Philippa's virtues, her epitaph comments that 'the plurality of them is impossible for the smallness of this stone to present'. ${ }^{48}$ This trope relates the monumentality of the tomb to Philippa's character, suggesting that even a memorial of such grand size is rendered 'small' by the vastly greater scale of the queen's virtue. ${ }^{49}$ The full meaning of this statement can only be understood by both reading and looking: the inscription states that the size of the monument is evidence of the queen's virtue, an assertion enhanced by the fact that to read this claim means standing at the point at which the stone tomb chest towers over the viewer (ftg. 14). Here we reach a new layer of complexity in the relationship between text and image. In Writing the Dead, Petrucci argued that the tombs of medieval pontiffs reduced the space allocated to sculpted epitaphs so as to 'prevent the spectator's eye being drawn away from the monument to the document, from the effigy itself ... to the text' ${ }^{\prime}{ }^{50}$ At Batalha, the reverse is true. Rather than the sculpted ftgures of the king and queen, it is the inscribed epitaph that is placed at eye-level and that thus dominates the viewer's experience of the memorial (ftgs. 4 and 5). Although the visual and textual elements of the tomb are designed to complement and reinforce one another, it is impossible to read and look simultaneously: to be close enough to study the small, dense Latin lettering also means standing at a point at which the effigies are raised too high above the viewer's head to be easily seen (ftg. 14). It is the epitaph that dictates the pace and rhythm of looking. The inscription requires the viewer to walk around the different sides of the monument in turn (starting with the south and ending with the north), stepping forwards to scrutinize the carved letters and then back to glimpse the effigies of the king and queen.

The placement of the epitaph at eye-level is thus an implicit demand to be read, but this raises the 
10. Line filler, detail of the epitaph to João, north face of the tomb chest

(photo: author)
11. Line filler, detail of the epitaph to Philippa, south face of the tomb chest (photo: author)

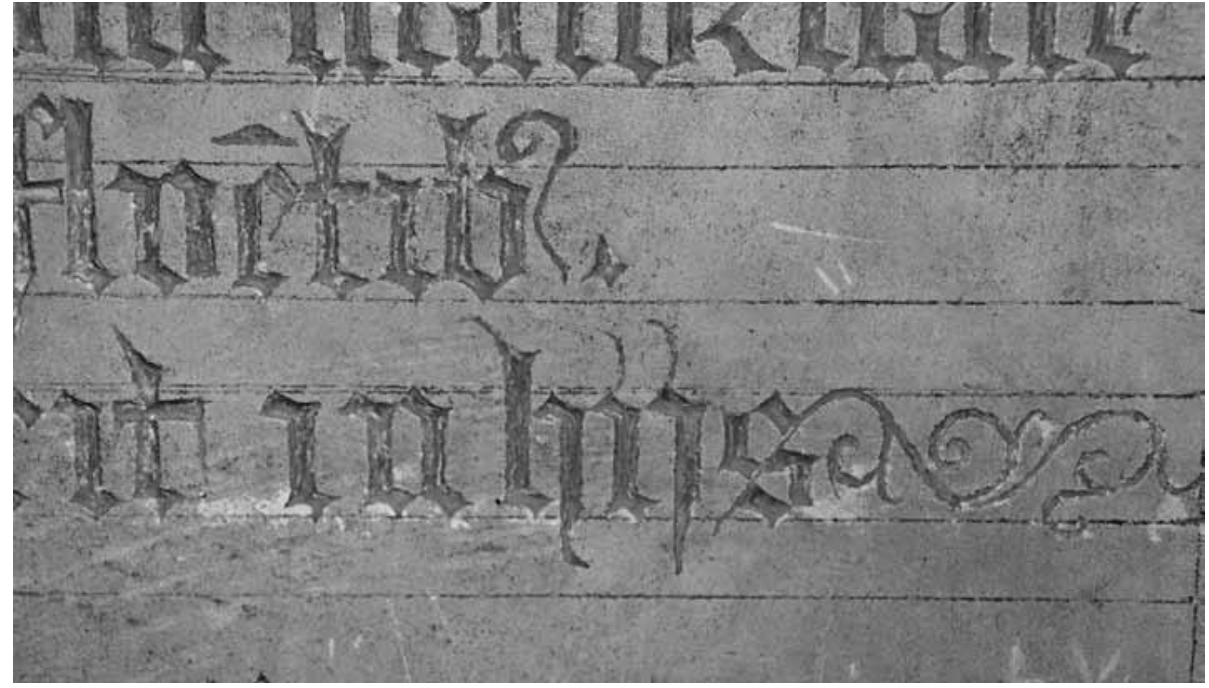

question: how many people in the ftfteenth century were able - and willing - to fulftl this command? The most frequent visitors to the Founder's Chapel would have been the Dominican friars resident at Batalha, a community who certainly would have been able to read Latin prose. The friars were required to spend many hours performing commemorative rites in close proximity to the monument: João's will of 1426 stipulates that the Masses of the Holy Spirit and Virgin Mary were to be said or sung daily for the souls of himself and Philippa; every Monday the friars were to perform the Office of the Dead and a Requiem Mass; and an additional versicle was to be sung for the queen after the friars had completed the daily offices and before they went to eat. ${ }^{51}$ Although the king does not specify the location of these services, they would almost certainly have taken place at the altar that once stood at the eastern end of the tomb, described by travellers in the eighteenth century, complete with a wooden altarpiece featuring a gilded low-relief carving of the Cruciftxion. ${ }^{52}$ It would have been impossible, however, for the friars to read the inscription on the north and south sides of the tomb chest when standing at the altar at the eastern end of the tomb. Indeed, an intended lay audience for the epitaph is implied by its remarkable lack of devotional formulae and emphasis on military and courtly virtues. Duarte, the patron of the epitaph, was well known for his literary erudition, authoring a number of works - including Leal Conselheiro, a book of advice for noblemen - during

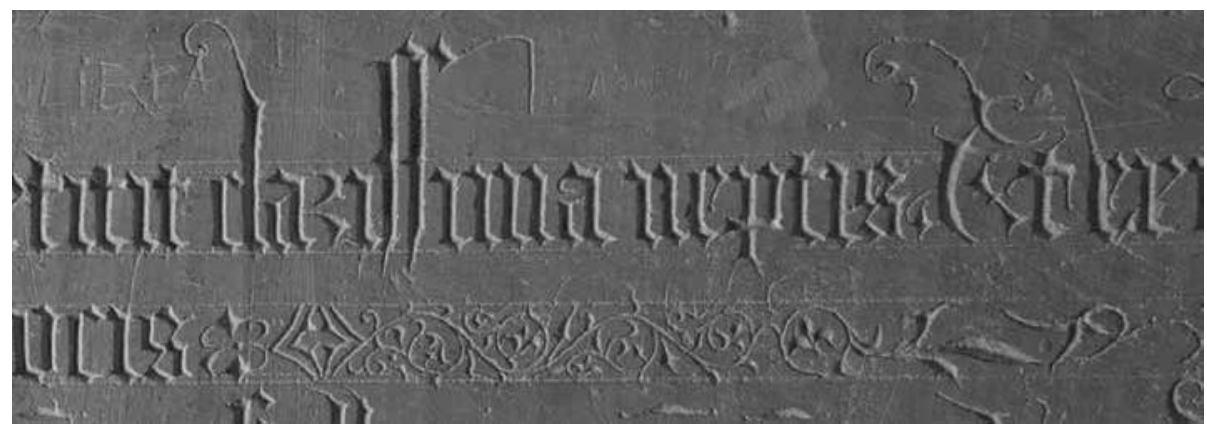


his short reign. The importance that the royal family placed on education was emulated by the wider court community, which enjoyed a reputation in the ftfteenth century as a fertile intellectual environment. ${ }^{53} \mathrm{As}$ the ftrst space in Portugal to be explicitly designated as a royal mausoleum, the Founder's Chapel was a stage for grand ceremonies involving a diverse - albeit elite audience. ${ }^{54}$ The epitaph itself records that the entire royal family, as well as 'the most eminent and powerful part of the prelates, lords and nobles of this land', were present in the chapel for the translation of João and Philippa's bodies. ${ }^{55}$ This large gathering would have been repeated at least once a year: it was common practice in the later Middle Ages for the anniversaries of royal and aristocratic funerals to be marked by the public distribution of alms, large-scale processions and elaborate liturgical rites, attended by friends and relatives of the deceased. ${ }^{56}$ The epitaph contains no less than four references to the vigil of the Assumption of the Virgin on 14 August, the date of João's death and the burial of the royal couple in the Founder's Chapel, suggesting that the text was intended for public performance as well as private contemplation, perhaps read aloud as part of the anniversary ceremonies prescribed in the king's will. ${ }^{57}$

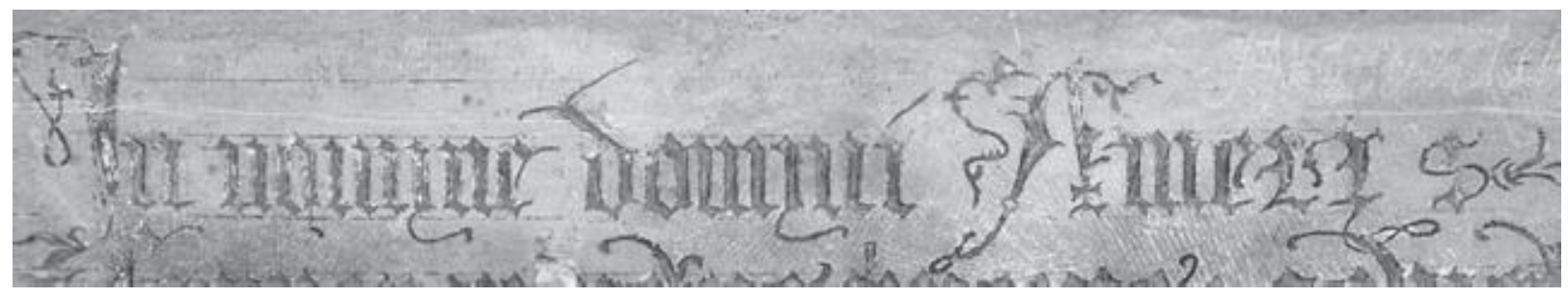

12. Heading: 'In nomine dominus. Amen', detail of the epitaph to João, north face of the tomb chest (photo: author)
Yet even for those friars, prelates and nobles who were fluent in Latin, the length of the text, its copious abbreviations and its linguistic complexity must have presented a signiftcant challenge. This raises the possibility that part of the 'meaning' of the epitaph resides precisely in its incomprehensibility: the difficulty we have in reading it. In On Longing: Narratives of the Miniature, the Gigantic, the Souvenir, the Collection, Susan Stewart emphasizes the importance of inscriptions in enhancing the authority of sculpted monuments, claiming that 'the reduction of the individual viewer in the face of the public monument is all the more evident in the function of the inscription; one is expected to read the instructions for the perception of the work' ${ }^{58}$ Following Stewart's argument, inscriptions enhance the authority of a monument over the viewer in two ways: the presence of the inscription is an implicit command to read, while the text itself dictates the meaning of sculpted images. At Batalha, the relationship between inscription and authority operates in a subtly different way. To borrow Stewart's phrase, the 'reduction of the individual viewer' in front of the tomb is prompted by the difficulty in meeting its demands: the presence of the inscription is an implicit command to read, but its length and language prevent easy comprehension. The sense of alienation produced by this wall of text emphasizes the 'other-ness' of the royal couple, an effect enhanced by the 


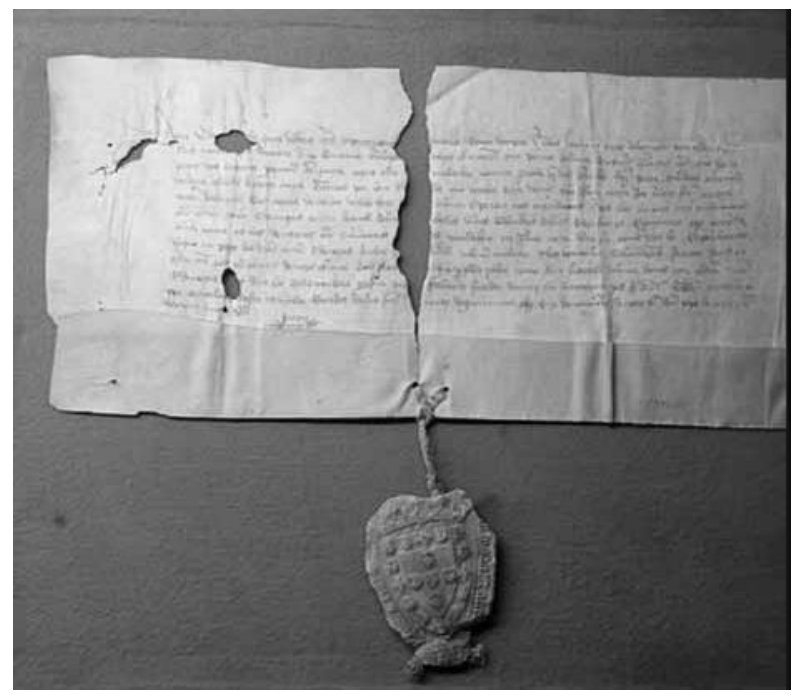

ornately carved effigies, which are elevated above the epitaphs and beyond the viewer's gaze. Here the line between sculpted word and sculpted image begins to blur. The inscribed words function in much the same way as the sculpted ftgures, communicating royal majesty through the content of their signs, but also (and perhaps more importantly) through the sense of awe and belittlement they prompt in the viewer.

Following the dissolution of the monastic orders in Portugal in 1834, the monastery at Batalha was transformed from a site of religious observance to a symbol of Portuguese national identity ${ }^{59}$ In 1983 the shift from monastery to museum was completed as Batalha was listed as

13. Charter of mercy granted by Duarte I to Leonel de Lima, 11 November 1433, parchment. Lisbon, Arquivo Nacional Torre de Tombo, PT/TT/VNC/C/1201 (photo: http://digitarq.arquivos. pt/)
14. Detail of the epitaph to Philippa, south face of the tomb chest (photo: author) a UNESCO World Heritage Site. The monument to João and Philippa has thus become accessible to a much more diverse audience, albeit one to whom the Latin epitaphs are almost universally abstruse. Abrasions to the surface of the stone and the near-total loss of pigment from the inscription on the south side of the tomb chest mean that the epitaph is even more difficult to read now than it was at the time the monument was erected; a situation evidenced by the fact that information plaques have been erected in front of the monument to identify the deceased. It could be argued that in this very incomprehensibility the epitaph retains part of its original function; now, as then, we are presented with a wall of text standing between ourselves and the sculpted bodies of the king and queen. On the other hand, the content of the text is rich in meanings intended to enhance the presentation of the royal effigies and reorientate our understanding of the space in which they are situated. It is hoped that the following translation, and the photographic record which accompanies it, will allow a contemporary audience to both look and read what is undoubtedly one of the most remarkable sculpted epitaphs from medieval Europe.

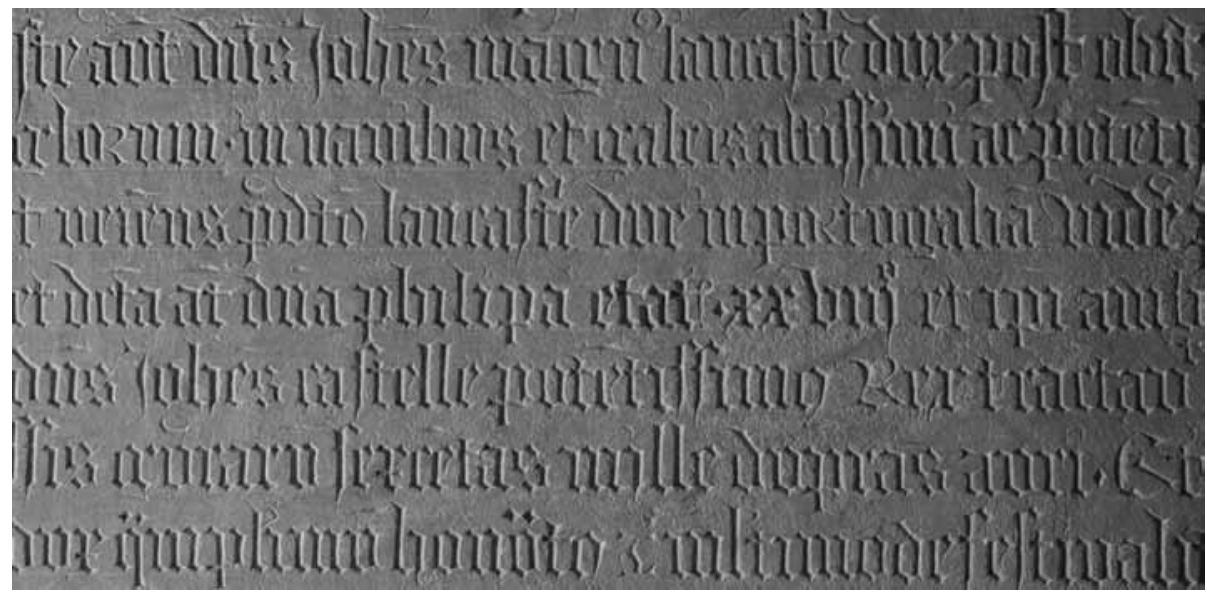


The research for this article was undertaken during a Henry Moore Post-Doctoral Research Fellowship, 2014-16. Thanks to Magda Hoyton for checking and advising on Latin translations; Pedro Redol for so generously sharing his expertise on Batalha and allowing me to access, measure and photograph the Founder's Chapel; and Joana Ramôa-Melo, Rosa María Rodríguez Porta, Filipe Alves Moreira, Maeve O'Donnell-Morales and Begoña Farré Torras for their advice on Portuguese medieval sculpture and Iberian

historiography. I am also indebted to Jack Hartnell, Luca Palozzi and Jana Gajdosova, who read and commented on drafts of this article.

1. P. Larkin, 'An Arundel Tomb', in The Whitsun Weddings, London, Faber \& Faber, 1964, pp. 45-46.

2. Ibid., p. 45

3. This intervention was carried out 1843 by the restorer and sculptor Edmund Richardson, who apparently used 29 pieces of stone from the base to restore the ftgures. The effigies had previously rested on two separate chests, arranged against the north wall of the northern outer aisle, with the ftgure of the lady at the feet of the knight. It is uncertain whether the current tomb chest retains any of the original fourteenthcentury stone. H. A. Tummers, 'The medieval effigial tombs at Chichester Cathedral', Church Monuments, III, 1988, pp. 31-61. See also P. Lankester, 'Notes and queries on a medieval tomb at Chichester', Newsletter of the Church Monuments Society, V, 1989, pp. 15-18; H. A. Tummers, 'Church monuments', in M. Hobbs (ed.), Chichester Cathedral: An Historical Survey, Chichester, Phillimore, 1994, p.211.

4. See, for example, S. Blair, Islamic Inscriptions, Edinburgh, Edinburgh University Press, 1998; A. Eastmond (ed.), Viewing Inscriptions in the Late Antique and Medieval World, Cambridge, Cambridge University Press, 2015; R. E. Harrist, The Landscape of Words: Stone Inscriptions from Early and Medieval China, Seattle, WA, University of Washington Press, 2008; L. James, 'And shall these mute stones speak? Text as art', in L. James (ed.), Art and Text in Byzantine Culture, Cambridge, Cambridge University Press, 2007, pp. 188-206; S. Franklin, Writing, Society and Culture in Early Rus, c. 950- 1300, Cambridge, Cambridge University Press, 2002.

5. For a more historical and/ or art-historical approach to the epitaph, see, for example, S. Badham, 'Status and salvation: the design of medieval brasses and incised slabs', Transactions of the Monumental Brass Society, XIV, 1996, pp. 376-94; J. Bertram, 'Inscriptions on late medieval brasses and monuments', in J. Higgett, K. Forsyth and D. N.
Parsons (eds), Roman, Runes and Ogham: Medieval Inscriptions in the Insular World and on the Continent, Donington, Shaun Tyas, 2002, pp. 190-201; N. Saul, English Church Monuments in the Middle Ages. Ritual and Representation, Oxford, Oxford University Press, 2010, pp. 335-65. For a more literary approach to the epitaph, see, for example, D. Griffith, 'A living language of the dead? French commemorative inscriptions from late medieval England', The Medixval Journal, III/2, 2013, pp. 69-136; D. Griffith, 'English commemorative inscriptions. Some literary dimensions', in C. M. Barron and C. Burgess (eds), Memory and Commemoration in Medieval England. Proceedings of the 2008 Harlaxton Symposium, Harlaxton Medieval Studies XX, Donington, Shaun Tyas, 2010, pp. 251-70; D. B. Tyson, 'The epitaph of Edward the Black Prince', Medium Aevum, XLVI, 1977, pp. 98-104.

6. A. Petrucci, Writing the Dead: Death and Writing Strategies in the Western Tradition, trans. M. Sullivan, Stanford, CA, Stanford University Press, 1998. A similar methodology is adopted in L. Palozzi, 'Petrarch and memorial art: blurring the boundaries between art theory and art practice', in A. Adams and J. Barker (eds), Revisiting the Monument. Fifty Years after Panofsky's Tomb Sculpture, London, Courtauld Books On-Line, 2016, pp. 89-112. A recent self-published book by Jerome Bertram, Icon and Epigraphy, 2 vols, Lulu Press, 2015, matches the ambition of Petrucci's range (albeit geographically rather than chronologically dispersed), but is less theoretical in approach.

7. Petrucci, as at note 6, pp. 56-57, 60.

8. There are two published Portuguese translations: one by Friar Luís de Sousa published in the seventeenth century, and one by José Neves published at the end of the nineteenth century. See L. de Sousa, Primeira parte da história de S. Domingos, 3rd edn, vol. 2, Lisbon, 1866, pp. 301-04, 306-08; J. Neves, Traducião do epitaphio latino El-Rey

D. João I, Alcobaça, 1891.

9. See, for example, J. Ramôa Melo and J. da Silva, 'O retrato de D. João I no Mosteiro de Santa Maria da Vitória', Revista de Historia da Arte, V, 2008, pp. 77-95, and accompanying photographs; J. da Silva and P. Redol, The Monastery of Batalha, London, Scala, 2007, pp. 75-80, and accompanying photographs. For the most recent (and extremely useful) article on the tomb, see J. Ramôa Melo, 'Um panteão régio tardo-medieval: inovação e tradicionalismo no programa funerário dos reis $\mathrm{D}$. João I e D. Filipa de Lencastre, no Mosteiro da Batalha', in J. Ramôa
Melo and L. Urbano Afonso (eds), $O$ fascínio do gótico. Um tributo a José Custódio Vieira da Silva, Lisbon, IHA, forthcoming 2017.

10. See, for example, the chapter on 'Inscriptions' in Saul, as at note 5, pp. 335-65.

11. da Silva and Redol, as at note 9 , pp. 78-80; Ramôa Melo and da Silva, as at note 9, p. 81 .

12. See da Silva and Redol, as at note 9, pp. 11-15, 75-83 and passim.

13. See the epitaph, line 114 [123] In this and subsequent references to the epitaph, the line number for the Latin transcription is given $\mathrm{ftrst}$ with the line number for the English translation following in square brackets.

14. See Chronica do Condestabre de Portugal Dom Nuno Alvarez Pereira, Subsidios para o estudo da Historia da Literatura Portuguesa XIV, Coimbra, 1911.

15. See lines 101 [109], 127-30

[136-39], 154 [164].

16. Lines 36-46 [41-52].

17. Lines 48-49 [54-55].

18. For the signiftcance of the hand-joining motif and a discussion of the marital references on the tomb at Batalha, see J. Barker, 'Monuments and marriage in late-medieval England', unpub. PhD thesis,

Courtauld Institute of Art, 2015, chapters 2 and 3.

19. See lines 62-63 [69-70]. For the long-standing Christian tradition of the 'odour of sanctity' and its role in the construction of holiness, see S. A. Harvey, Scenting Salvation: Ancient Christianity and the Olfactory Imagination, Berkeley, CA, University of California Press, 2006, pp. 227-29; M. Roch, L'intelligence d'un sens: Odeurs miraculeuses et odorat dans l'Occident du haut Moyen Âge (V'-VIII siècles), Turnhout, Brepols, 2009, pp. 249-328.

20. The queen's ftrst burial in the choir at Batalha is also recorded in a (much-damaged) Latin verse epitaph set into the west wall of the south transept of the monastery church. See S. A. Gomes and A. M. Rebelo, 'O primeiro epitáfto latino de D. Filipa de Lencastre no Mosteiro de Batalha', Leira-Fátima, Órgão Oficial da Diocese, XLIV, 2008, pp. 177-92.

21. Lines 60-73 [67-81].

22. Lines 134-61 [144-71]

23. See J. Barker, 'Stone and bone: the corpse, the effigy and the viewer in late-medieval tomb sculpture', in Adams and Barker, as at note 6, pp. 113-36.

24. Lines 71-72 [79-80].

25. Line 72 [78], 81 [88], 156 [166]

26. Although most published work on semblanzas focuses on Castile and Aragón, the biographies of Philippa and João in the Crónica de D. João I by Fernão Lopes clearly belong to the same tradition. See Fernão Lopes, Cronica del Rei Dom Joham I de boa memoria e dos Reis

de Portugal o decimo, vol. 2, ed. W. J. Entwistle, Lisbon, Imprensa Nacional, 1968, part 2, prologue, pp.1-3; ch. XCVIII, pp. 211-12. For Castile, see R. Folger, Generaciones y semblanzas: Memory and Genealogy in Medieval Iberian Historiography, Tübingen, Gunter Narr Verlag, 2003; R. Folger, "WWriting in the heart": Generaciones $y$ semblanzas and Ystoria troyana', Revista Canadiense de Estudios Hispánicos, XXVIII, 2003, pp. 313-31; R. Folger, 'A genealogy of Castilian historiography: from Nomina Regnum to Semblanzas', La córonica, special issue, The Historian's Craft in Medieval Iberia, XXXII/3, 2004, pp. 49-68; M. López Casas, 'La técnica del retrato en las "Generaciones y semblanzas" de Pérez de Guzmán y las artes poéticas medievales', Revista de literatura

medieval, IV, 1992, pp. 145-62.

27. Folger, Memory and Genealogy, as at note 26 , pp. $14-15,52,81,190-91$. López Casas, as at note 26, p. 158.

28. A similar combination of narrative history and semblanzas is found in Castilian chronicles. Folger, Memory and Genealogy, as at note 26, pp. 14-15, 44-52, 185-95.

29. Folger, 'Genealogy of Castilian Historiography', as at note 26, p. 63. For the connections between literary and monumental commemoration in medieval Iberia, see T. Nickson, 'Remembering Fernando: multilingualism in medieval Iberia', in Eastmond, as at note 4, pp. 177-79. For semblanzas as aids to forming mnemonic images, see R. M. Rodríguez Porto, '“Otros reyes de la su casa onde él venía": metáforas, diagramas y ftguras en la historiografía Castellana (1282-1332)', Revista de poética medieval, XXVII, 2013, pp. 197-232.

30. Folger, Memory and Genealogy, asatnote26,pp.50-51.

31. In a letter dated 19 March 1434 Duarte entrusts Ferñao Lopes with the task of chronicling the history of the kings of Portugal up until the reign of his father, João. See $\mathrm{T}$. Amado, 'Fernão Lopes', in G. Lanciani and G. Tavani (eds), Dicionário da literatura medieval galega e portuguesa, Lisbon, Caminho, 1993, pp. 271-73; Derek W. Lomax and R. J. Oakley (trans. and ed.), The English in Portugal, 1367-1387: Extracts from the Chronicles of Dom Fernando and Dom João, Warminster, Aris \& Phillips, 
and monasteries to gather historical information, while Lopes himself refers to his use of 'public writings' as sources in the prologue of the ftrst part of the Cronica del Rei Dom Joham I. See G. E. de Zurara, Crónica de tomada de Ceuta por el Rei D. João I, rev. edn, Lisbon, Academia de Sciências de Lisboa, 1915, ch. III, pp. 12-13; Fernão Lopes, as at note 26, part 1, prologue, p. 2. Many thanks to Filipe Alves Moreira for alerting me to these references.

36. See M. Van Dussen, 'Three verse eulogies of Anne of Bohemia', Medium Aevum, XV, 2005, p. 283 n. 23; V. Gillespie, 'Medieval hypertext. image and text from York Minster', in P. R. Robinson and R Zim (eds), Of the Making of Books: Medieval Manuscripts, their Scribes and Readers. Essays Presented to M. B. Parkes, Aldershot, Ashgate, 1997, pp. 207-29; G. Gerould, “"Tables" in mediaeval churches', Speculum, I/4, 1926, pp. 439-40; J. Krochalis, 'Magna Tabula: the Glastonbury tablets', in J. P. Carley (ed), Glastonbury Abbey and the Arthurian Tradition, Cambridge, D. S. Brewer, 2001, pp. 435-568. Although these references focus on English examples, there is evidence that similar tablets were displayed in Rome, Loreto, Zurich and eastern Europe.

37. For the tomb to Richard II and Anne of Bohemia, see M. Duffy, Royal Tombs in Medieval England, Stroud, Tempus, 2010,pp.163-73.

38. The textual evidence indicates that the poems were composed soon after Anne's death in 1395. Van Dussen dates the Bohemian traveller's visit to Westminster toc. 1402-c. 1413. M. Van Dussen, From England to Bohemia: Heresy and Communication in the Later Middle Ages, Cambridge, Cambridge University Press, 2012, pp. 21, 23-26, 130, 138; Van Dussen, as at note 36, pp. 231-60. Other examples of epitaphs displayed next to a tomb on parchment tablets include Geoffrey Chaucer's Latin epitaph by the mid-ftfteenth-century Italian humanist Stephen Surigo, displayed next to his tomb in Westminster Abbey, and the early sixteenthcentury eulogies to Henry VII and Elizabeth of York, displayed on tablets close to their tombs in the Lady Chapel at the Abbey. See Gillespie, as at note 36, p. 217; Krochalis, as at note 36, pp. 441-42.

39. For a transcription and translation of the epitaphs, see Van Dussen, as at note 38, pp. 130-41.

40. Richard II ordered 'twelve images of the said gilt metal of representations of diverse saints' and 'escutcheons, wel proportioned of the said gilt metal, engraved and enamelled of diverse coats of arms' in his contract for the tomb, drawn up with the coppersmiths Nicholas Broker and Godfrey Prest in 1395. Although all have been stolen, their original positions can be ascertained from the empty niches and ftxing holes on the Purbeck marble tomb chest. S. Badham and S. Oosterwijk, "“Cest endenture fait parentre": English tomb contracts of the long fourteenth century', in S. Badham and S. Oosterwijk (eds), Monumental Industry: The Production of Tomb Monuments in England and Wales in the Long Fourteenth Century, Donington, Shaun Tyas, 2010, pp. 200-03. For the inscription, see Duffy, as at note 37, pp. 171-72. Only the section of the inscription on the north side of the tomb (facing the Confessor's Chapel) is fully visible; the west and east sides are partially concealed by the piers, while the south side faces the ambulatory, meaning it is elevated too high above the viewer's head to be seen.

41. Afonso's recently conserved memorial in Braga Cathedral features a gilt cast-copper alloy effigy with silvered details, the draped cloth and the child's long robe decorated with pointillé flowers, trees and plants. The use of a metal effigy was unprecedented in Portugal, while the delicate incised motifs on the ftgure of Afonso closely parallel the decoration on the effigies of Richard II and Anne. Although they could not have seen the Westminster tomb in person, it is probable that Philippa and João were instructing Portuguese artists to use materials and techniques that had been described to them by English associates. Philippa regularly wrote to correspondents in England, with surviving letters written from the queen to Richard II. See S. Badham and S. Oosterwijk, "“Monumentum aere perennius"? Precious-metal effigial tomb monuments in Europe, 1080-1430', Church Monuments, XXX, 2015, pp. 79-88; Barker, as at note 18 , pp. 133, 136-37.

42. F. P. Macedo and M. J. Goulão, 'Les tombeaux de Pedro et Inês: La mémoire sacralise d'un amour clandestin', in W. Reinink and J. Stumpel (eds), Memory and Oblivion: Proceedings of the XXIXth International Congress of the History of Art held in Amsterdam, 17 September 1996, Dordrecht, Kluwer Academic Publishers, 1999, pp. 491-97. See also the Imago database of Portuguese art, http:// imago.fcsh.unl.pt/ (accessed 16 October 2015)

43. Compare, for example, the epitaph on the tomb of Pedro de Meneses and Beatriz Coutinho, made in 1455-62, at the Igreja de Santa Maria da Graça, Santarém, and the Book of Hours of Don Duarte, made in c. 1401-33 (Portugal, Torre do Tombo, Ordem de São Jerónimo, Mosteiro de Santa Maria de Belém, liv. 65). For textualis in Portuguese manuscripts, see A. Derolez, The Palaeography of Medieval Manuscript Texts, From the Twelfth to the Early Sixteenth Century, Cambridge, Cambridge University Press, 2003, pp. 111-16, plate 73.

44. The polychromy of the tomb chest is currently being analysed as part of a project run by the Instituto de História da Arte (Universidade Nova de Lisboa), called 'Monumental Polychromy: revealing medieval colours at Batalha', ftnanced by Fundação Calouste Gulbenkian and carried out by researchers from Instituto de História da Arte (Universidade Nova de Lisboa), Mosteiro da Batalha, Laboratório Hercules (Universidade de Évora), Instituto Politécnico de Leiria and Instituto Português de Heráldica. Thanks to Joana Ramôa Melo for providing this information.

45. For medieval documents, see J. Berenbeim, Art of Documentation: Documents and Visual Culture in Medieval England, Toronto, Pontiftcal Institute of Medieval Studies, 2015.

46. J. Luxford, 'Tombs as forensic evidence in medieval England', Church Monuments, XXIV, 2009, pp. 7-25. 60

47. Petrucci, as at note $6, \mathrm{pp} .56-57$

48. Line 51 [57]. A similar statement on the impossibility of praising all of Philippa's virtues occurs in the Crónica de D. João I, chapter XCVIII. See Fernão Lopes, as at note 26, part 2, p. 211

49. The 'small stone' is a rhetorical commonplace often found on medieval epitaphs. One famous example is Petrarch's epitaph for the tomb of Jacopo da Carrara, which refers to the great man lying 'sub marmore parvo' [under a small stone]. For Carrara's epitaph, see Palozzi, as at note 6, pp. 89-112.

50. Petrucci, as at note 6, p. 56.

51. The Masses of the Holy Spirit and Virgin were spoken on Mondays, Tuesdays, Wednesdays and Sundays, while on Thursdays the Mass of the Holy Spirit was sung and the Mass of the Virgin was spoken, and on Sundays the Mass of the Virgin was sung and the Mass of the Holy Spirit was spoken. S. A. Gomes (ed.), Fontes históricas e artísticas do mosteiro e da vila da Batalha: séculos XIVaXVII,vol.1,1388-1450,Lisbon, Instituto português do património arquitectónico, 2002, doc. 52, p. 137. See also P.Soares and P. Redol (eds), Places of Prayer in the Monastery of Batalha (exh. cat.), Monastery of Batalha, Batalha, 2015, pp. 77-78.
52. J.Murphy, Plans, Elevations, Sections and Views of the Church of Batalha, London, 1795, pp. 33, 35; T. Pitt, Observations in a Tour to Portugal and Spain (1760) [Observacões de uma viagem a Portugale Espanha, 1760], ed. M.J. Neto, Lisbon, Instituto Português do Património Arquitectónico, 2006, p. 135. The altar is depicted in an engraving of the Founder's Chapel (after a painting by James Holland) published in W. H. Harrison, The Tourist in Portugal, London, Robert Jennings, 1839, opposite p. 232.

53. See L. M. Duarte, D. Duarte: Réquiem por um rei triste, Reis de Portugal Series, Lisbon, Temas e Debates, 2007, pp. 34-35, 197-212.

54. Gomes, as at note 51 , doc. 52 , pp. 138-39. João's predecessors were buried in a number of different religious establishments, including Alcobaça and Coimbra, and all have their monuments within the main body of the church rather than a separate chapel. See da Silva and Redol, as at note 9, pp. 75-77; Ramôa and da Silva, as at note 9, pp.77-79.

55. Lines 154-62 [165-70].

56. One of the best-documented examples of this practice are the elaborate ceremonies accompanying the anniversaries of Philippa's mother, Blanche of Lancaster, at the cathedral of Old St Paul's in London, recorded in the account books of her father, John of Gaunt. See N. B. Lewis, 'The anniversary service for Blanche, Duchess of Lancaster, 12th September, 1374', Bulletin of John Rylands Library, XXI, 1937, pp. 176-92.

57. 14 August would have been the height of the commemorative rituals in the Founder's Chapel as it was the only date when the friars would have been required to perform all the prayers and masses prescribed for the anniversaries of the king and queen's funerals, as well as the additional trimtayro [month's mind] - involving monks from Alcobaça and other visitors to the monastery - prescribed for theanniversaries of the king and queen's deaths. Gomes, as at note 51, doc. 52, p. 137. See also Soares and Redol, as at note 51, pp. 77-78.

58. S. Stewart, On Longing: Narratives of the Miniature, the Gigantic, the Souvenir, the Collection, Durham, NC, Duke University Press, 1993, p. 90.

59. On the secularization of the Founder's Chapel in the nineteenth century, see B. F. Torras, 'Brotherly love and ftlial obedience: the commemorative programme of the Avis princes at Santa Maria da Vitória, Batalha', unpub. Master's thesis, Universidade Nova de Lisbon, 2014, pp. 90-95. 


\section{Transcription and translation of the epitaph of João I and Philippa of Lancaster, King and Queen of Portugal}

Jessica Barker

South side: Philippa's epitaph

Serenissima et excellentissima: ac honestissima et valde devota Regina Domina Philipa. ${ }^{1}$ Serenissimi Eduardi Anglie peroptimi Regis et Regine consortis sue extitit clarissima neptis. Et ex utroque parente Henrici quarti Anglorum serenissimi Regis illustissima soror, et filia domini Johannis ducis Lancastrie praeffati Regis Eduardi filii p[rae]clarissimi. Et domine Blanche ducisse Lancastrie filie et heredis unice Henrici Lancastrie peroptimi ducis. [line decoration]

Iste autem dominus Johannes magnus Lancastrie dux post obitum dicte domine Branche mutavit2 cum l ${ }^{3}$ [blank space] domini Petri Castele Serenissmi Regis matrimonium. Ob quod ius habens ad ipsum Castelle Regnum non modice praetendebat. Et sub hoc titulo et regio nomine venit cum potestate gentium dominium Anglorium in navibus et galeris altissimi et potentissimi principis domini Johannis Portugalie excelentissimi Regis, et in galleciam transfretavit. Ibique obtinuit municionem et vilam de Crunha et alias municiones, que illi tanquem suo legitimo regi obedierunt.

Et veniens predictus Lancastrie dux in Portugaliam videre preffatum dominum Johannem Regem invictissimum eidem in matrimonio copulavit prelibatam dominam Philipam suam priorem genitam illustrissimam anno domini $m$ ccc lxxx vii. Erat nempe tempore dicte desponsationis dictus Rex etatis xxix annorum et dicta autem domina Philipa etatis xxviii et ipsi ambo principes intrarunt pariter Regnum Castelle, varias municiones subiciendo, tam ardua quam magnifica opera peregerunt tanteque in dicto Castelle Regno perseverarunt, quod altissimus et excellentissimus. Dominus Johannes Castelle potentissimus Rex tractavit cum preffato Lancastrie duce quod infans dominus Henericus eiusdem Regis filius primogenitus uxoraret cum domina Catherina dicti ducis filia et domini Petri Regis Castelle nepte. Deditque dictus dominus Johannes Castelle Rex prelibato domino duci pro factis expenssis guerarum sexcentas mille dupras auri. Et se obligavit singulis annis vitae dicti ducis quadraginta mille dupras eidem soluturum. Et cum hoc tractatu redierunt preffati domini in Portugaliam ibique per serenissimum dominum Johannem istorum Regnorum gloriossimum Regem extitit dictus Lancastrie dux quamplurimum honoratus et multimode festivaliter iocundatus. Et magnifica munerum distributio per hunc Regem, et barones et proceres, et cet[er]os elargita, et donaria prout decebat regiam magestatem impenssa, gratissime 
universsos indeffectibiliter iocundarunt. Et disposita per dictum Portugalie Regem potenti et tota classe. Regressus est ad dominium Anglie, in eadem dux prelibatus. Manente domina Philipa eiusdem ducis filia cum Rege domino Johanne, istorum Regnorum gloriosa Regina.

Haec felicissima Regina a puellari aetate, usque in suae terminum vitae, fuit Deo devotissima: et divinis officiis ecclesiasticae consuetis tam diligenter intenta, quod clerici literati et devoti religiosi erant per eandem saepius eruditi: in oratione autem erat tam continua, quod demptis temporibus gubernatione vitae necessariis, contemplationi et lectioni, seu devotae orationi totum residuum applicabat. Plurimum vero fidelissime dilexit proprium virum: et moralissime proprios filios castigando virtuosissima doctrinavit: et bona temporalia circa ecclesias et monasteria distribuendo pauperibus plurima erogabat: generosis Domicellis maritandis manus liberalissimas porrigebat. Eratenim integrapopuli amatrix et pacis plena desideratrix, et efficax adjutrix ad pacem habendam cum Christicolis universis, et libenter assentiens in devastationem infidelium pro Dei injuria vindicanda: et tante prona etiam ad indulgentiam, quod nunquam accepit de sibi errantibus, nec consensit vindicatam fieri aliqualem.

Virtuosissima ista Domina extitit faeminis maritatis bene vivendi regulare exemplar, Domicellis directio et totius honestatis occasio: cunctisque suis subjectis fuit curialis urbanitatis moderatissima doctrix. In his autem et aliis quamplurimis perseverando virtutibus, quarum plurimitatem hujus lapidis brevitas nequiret ullatenus praesentare, dietim et continue meliorando, pervenit ad istius vivendae mortalis limitem ordinatum: et sicut eius vita fuit optima et valde sacra, sic mors extitit pretiosa in conspectu Domini, et nimium gloriosa: et receptis laudabiliter omnibus Eccleiasticis Sacramentis proprios filios benedixit commendans eisdem quae intendebat fore ad Divinum obsequium et honorem et profectum istorum Regnorum, et quae in eisdem sperabat causatura crementum indubie: virtuosissimae, taliterque huis mundi labores finaliter adimplevit, quod praesentes, et abssentes qui relata audierunt, firmam suae salvationis spem retinent singularem.

Obiit autem decima octava die Julii anno Domini M CCCC XV et in Monasterio de Odivellis ante chorum Monialium decima nona die mensis eiusdem extitit sepulta: et anno sequenti, mensis Octobris die nona fuit praetiosum corpus eius desepultum, integrum inventum et suaviter odoriferum, et per victoriosissimum Regem dominum Johannem eius conjugem, et per illustrissimos Infantes, scilicet, dominum Eduardum suum primogenitum, et dominum Petrum Colimbriae ducem, et dominum Henricum ducem Viseensem, et dominum Johannem, et dominum Fernandum, et Infantem dominam Elisabeth, ipsius gloriosissimi Regis et felicissimae Reginae filios: sociante praelatorum, et clericorum, et religiosorum copiae numerosae, et dominis et generosis dominabus, et domicellis quamplurimis comitantibus, fuit corpus dictae Reginae honorandissime translatum ad istud Monasterium de Victoriam, et tumulatum in capella majori et principaliori, die mensis octobris decima quinta Anno Domini M CCCC XVI: et postea fuit translatum ad hanc Capellam, in hoc tumulo 
reconditum cum corpore gloriosissimi Regis Domini Johannis, sui conjugis virtuosissimi, sub illa forma quae in suo epitaphio continetur. Horum autem personas Deus Omnipotens glorificare dignetur perpetuae faelicitate.

Amen.

North side: João's epitaph

In nomine Domine. Amen.

Serenissimus et semper invictus Princeps, ac victoriosissimus et magnificus resplendens virtutibus, Dominus Joannes Regnorum Portugalliae decimus, Algarbii sextus Rex: et post generale Hispaniae vastamen primus ex Christianis famosae civitatis Ceptae in Africa potentissimus Dominus, praesenti tumulo extat sepultus.

Excellentissimus iste Rex nobilissimae ac fidelissiae civitatis Ulixbonae ortus anno Domini M CCC LVIII, extitit per serenissimum domninum Petrum suum genitorem militaribus in aetate quinquennii ibidem decorates insigniis: et suscipiens, post decessum Regis Ferdinandi fratris sui, ipsius Lixbonensis urbis et aliarum complurium municionum, quae se illi subdiderunt, gubernamen, obsessam personaliter per Regem Castellae novem mensibus Ulixbonam mari grandissimae classe, et per terram ingenti vallatam exercitu, et plurimis Portugalensium Regis Castellae potentiam roborantibus circumseptam, adversus feras et multiplices impugnationes ipsam Ulixbonensem civitatem strenuissime defensavit.

Deindenobiliscivitatis Colinbrae AnnoDominiMCCCLXXXViocundissime sublimatus in Regem, per se and per suos bellicos proceres miranda exercuit guerrarum certamina: et pluries adversantium dominia et terras intrando gloriosissimus triumphavit:et praecipuam, et Regiam circa istudMonasterium victoriam est adeptus: ubi Regem Castellaedominum Johannem, suorum maximo firmatum robore nativorum, et plurium Portugaliensium et aliorum extraneorum fultum subsidiis, iste invictissimus Rex, virtute Dei Omnipotentis, potentissime debellavit: et quamplures istius Regni municiones et castra iam sub hostium redacta potestate, viribus recuperavit armorum, usque in suae vitae terminum virtuoissime protegendo. Et Deo recognoscens, gloriosissimaeque Virgini Mariae, Dominae nostrae, potissimam victoriam, quam in vigilia Assumptionis obtinuit in mense Augusti, hoc Monasterium in eorum laudem aedificari mandavit, prae caeteris Hispaniae singularius et decentius. Et soli Deo optans honorem et gloriam exhiberi, et tantum ipsi aut propter eum maioritatem fore cognoscendam descriptionem, quae suorum praedecessorum temporibus in publicis scripturis sub Aeram Caesaris notabatur, decrevit sub anno Domini nostrum Jesu Christi fore de caetero annotandam. Hoc actum est Aera Caesaris M CCCC LX et anno Domini M CCCC XXII, tempore aliter defluendo.

Iste felicissimus Rex, non minus reperiens quae susceperat Regna illicitis subjecta moribus, quam saevis hostibus, ipsa expurgavit cum diligentia 
salutari, et propriis actibus virtuosis usitata facinora extirpando, pullulare fecit in his Regnis probitates honestas: et sollicitus ad pacem cum Christianis amplectendam, eandem ante proprium decessum pro se suisque successoribus obtinuit perpetuam.

Et subcenssus fidei fervore iste Christianissimus Rex, comitante eundem Serenissimo Infante Domino Eduardo suo filio primogenito et haerede, et Infante Domino Petro, et Infante Domino Henrico, et Domino Alfonso Comite de Barcellos praefati Regis filiis. Et ingenti suorum naturalium et impavida sociatus potentia, cum maxima classe plus quam ducentis viginti aggregata navigiis, quorum pas numerosior maiores naves et grandiores extitere triremes in Africam transfretavit, et die prima qua telluri Afrorum impressit vestigia, nobilem et munitissimam civitatem Ceptam oppugnando in suam potestatem redegit mirifice, et postmodo eidem urbi plus quam centum mille (ut asseritur) Agarenorum ultramarinis, et Granatae pugnatoribus obsessae idem gloriossimus Rex per suos illustres genitos, Infantem dominum Henricum, et Infantem dominum Johannem, et dominum Alfonsum Comitem de Barcellos, et alios dominos, et generosos subcursum misit: qui fugantes de obsidione Agarenos quamplurimos in ore gladii trucidando; ipsorum classe submersione, incendio, et captura conquassata; praedictam liberavit civitatem Ceptam: quam decem et octo annis minus octo diebus anno Domini M CCCC XXXIII in mense Augusti, vigilia Assumptionis Sanctissimae Mariae Virginis terminatis adversus bellicos Agarenorum multiplicatos, insultus validissime praesidiavit. ${ }^{4}$ Mense autem et vigilia praedictis, iste gloriosissimus Rex in civitate Ulixbonae, assistentibus suis filiis et aliis quamplurimis generosis, vitam feliciter complevit mortalem, relinquens notabilem urbem Ceptam sub potestate altissimi et potentissimique Domini Eduardi filii eius, qui paternos actus viriliter imitando, eandem in fide Jesu Christi nititur prospere gubernare.

Iste autem excellentissimus, et virtuosissimus Rex Dominus Eduardus transtulit honorantissime corpus Christianissimi Regis patris sui, assistentibus eidem suis germanis, Infante domino Petro duce Colimbriae, et Montis Maioris domino; Infante domino Henrico duce de Viseo, et domino Covillianae, et gubernatore magistratus Christi; Infante domino Johanne comitestabili Portugaliae, et gubernatore Magistratus Sancti Jacobi; et Infante domino Ferdinando, et domino Alfonso, comite de Barcellos, filiis praefati Regis domini Johannis, qui tempore sui obitus alios non habebat, praeter duas filias, quarum una erat Domina Infans Elisabeth, Ducissa Burgundiae, et Comitissa Flandriae, et aliorum Ducatiuum, et Comitatuum: et alia Domina Beatrix Comitissa Hontinto et Arondel, quae in suis terris permanebant. Habebat autem predictus Rex dominus Joannes nepotes qui Dominicae translationi affuerunt, dominum Alfonsum comitem de Ourem, et dominum Ferdinandum comitem de Arrayolos, filios comitis de Barcellos: et habebat nepotem Infantem dominum Alfonsum progenitum domini Eduardi, et alios nepotes, et pronepotes qui annumerati cum filiis erant viginti, tempore quo de praesenti saeculo migravit ad Dominum. Affuerunt etiam huis translationis celebritati omnes qui tunc in cathedralibus ecclesiis istorum Regnorum praelati erant, et alii quamplures cum multitudine clericorum et religiosorum copiosa: et 
domini et generosi huius patriae, civitatum etiam et municionum procuratores extitere praesentes. Fuit autem venerandissime delatum Regium corpus eius ad istud monasterium trigesima die Novembris Anno Domini supradicto, et in capella maiori sepultum cum excellentissima et honestissima, et Christianissima Domina Philippa eius unica uxore, praedictorum Regis Eduardi et Infantum, et Ducisae Ilustrissimae genetrice. Anno vero sequenti die decima quarta mensis Augusti, fuere per Regem Eduardum, et Infantes et comites praelibata corpora praedictorum Regis Johannis, et Reginae Philippae cum honore mirifico ad hanc Capellam delata, quam aedificari pro sua sepultura imperavit, et huic deductione extitere praesentes altissima et excellentissima princeps domina Leonor horum Regnorum Regina, et Infans domina Elisabeth ducissa Colimbriae, et Infans domina Elisabeth uxor Infantis Domini Johannis, et praecipua et potior pars prelatorum, dominorum et generosorum istius terrae, qui interfuerunt sepulturis praedictorum Dominorum Regis et Reginae, quibus Deus sua miseratione et pietate largiri dignetur sine fine felicitatem. Amen.

South side: Philippa's epitaph

The most serene and excellent and honourable and exceedingly pious Queen, Dona Philippa. ${ }^{5}$ She stood forth as the most celebrated granddaughter of the most serene Edward, greatest King of England and the Queen his wife. ${ }^{6}$ She was also the most illustrious sister (from both parents) of Henry the Fourth most serene King of England, ${ }^{7}$ and the daughter of Lord John Duke of Lancaster, most excellent son of the aforesaid King Edward, ${ }^{8}$ and of Blanche Duchess of Lancaster, who was the daughter and sole heiress of Henry of Lancaster, the most excellent Duke. ${ }^{9}$

However, this man, the Lord John, great Duke of Lancaster, after the death of the aforesaid Lady Blanche, ${ }^{10}$ exchanged matrimony with [Constanza of Castile, daughter ${ }^{11}$ of Dom Pedro the most serene King of Castile. ${ }^{12}$ Having the right on account of this, ${ }^{13}$ he began to claim the Kingdom of Castile for himself without moderation. Under this title and with the name of king, he came with an army of Englishmen ${ }^{14}$ in ships and galleys belonging to the most high and powerful prince, the most excellent Dom João King of Portugal, ${ }^{15}$ and he sailed across in a galley. And there he took hold of the fortress and town of La Coruna and other fortiftcations, and they, as if to their rightful king, swore obedience. ${ }^{16}$

And coming to Portugal to see the aforesaid Dom João most victorious King, the aforesaid Duke of Lancaster joined to him in matrimony his eldest child, the aforesaid ${ }^{17}$ most illustrious Lady Philippa, in the year of Our Lord 1387. ${ }^{18}$ Indeed at the time of the said marriage the said King was twenty-nine years old but the said Lady Philippa was twenty-eight. Both princes themselves entered the Kingdom of Castile in a like manner, overthrowing various fortiftcations, they carried out deeds as arduous as they were heroic, and they persevered greatly in the Kingdom of Castile, which [is] most high and excellent. ${ }^{19}$ Don Juan most powerful King of Castile ${ }^{20}$ entered into a treaty with 
the aforesaid Duke of Lancaster that the Infante Don Enrique, ${ }^{21} \mathrm{ftrstborn}$ son of the same king, would marry Lady Catherine the daughter of the said Duke and granddaughter of Pedro King of Castile.22 And the aforesaid Don Juan King of Castile handed over 600,000 doblas of gold ${ }^{23}$ to the aforesaid Lord Duke on account of the expenses incurred during the war. And every year of the said Duke's life he was bound [to pay] him 40,000 doblas for the same reason. And with this treaty the aforesaid lords returned to Portugal and there the aforesaid Duke of Lancaster was honoured so greatly and joyfully celebrated in many ways by Dom João, the most glorious King of those Kingdoms. And [there was] a magniftcent distribution of gifts throughout that Kingdom, lavished on lords, and prominent administrators, ${ }^{24}$ and the rest, and - as was fttting - offerings were devoted to the royal majesty. Everyone ${ }^{25}$ rejoiced ceaselessly with the most gratitude. And with the army and the whole fleet arranged by the said King of Portugal, he, the aforesaid Duke, returned to the dominion of England in the same way [as he had come], while the daughter of the same Duke, Lady Philippa, remained with the King Dom João to be the glorious Queen of those Kingdoms.

This most blessed Queen was entirely devoted to God from her childhood until the end of her life. She was so attentive to the customary Divine Offices of the Church ${ }^{26}$ that learned clerics and pious monks were more often instructed by her. ${ }^{27}$ In prayer, however, she was so unremitting that, apart from the time required for the governance of her life, she was accustomed to apply the whole remainder to contemplation, reading, or devout prayer. But most of all, she loved her own husband most faithfully: and morally reproving her own children, she, most virtuous, instructed them. She dispersed temporal gifts around the churches and monasteries, distributing the most to the poor. She most freely offered her consent to those ladies in waiting who were to be wed. For she was an irreproachable friend of the people, a wholehearted petitioner for peace, and a powerful aide for the cause of peace with all Christians, freely agreeing to the destruction of the inftdels in order to avenge offence towards God. Yet she was so greatly inclined to forgiveness that she never took from those who erred against her, nor did she agree to any kind of vengeance.

This most virtuous lady stands out as an exemplar of good living for married women, a guiding direction for her ladies in waiting, and the occasion of absolute honour: and with all of her subjects she was the most moderate teacher of courtly sophistication. Persevering in these and so many other virtues, the plurality of which the smallness of this stone cannot in any way present, daily and continually improving, she arrived at the preordained limit of her mortal life. Just as her life was most excellent and exceedingly holy, so her death stood out in its great value in the sight of God, and glorious beyond measure. ${ }^{28}$ Having received all the sacraments of the Church in a praiseworthy manner ${ }^{29}$ she blessed her own sons, recommending to them that which she felt would ensure obedience to God and the honour and success of their kingdoms, and that which she hoped would certainly cause an increase in those kingdoms. Most virtuously and in such a way she ftnally fulftlled the 
labours of this world, so that those present, as well those who were absent that heard the reports, retain a ftrm and matchless hope for her salvation.

She died on the eighteenth day of July in the year of our Lord 1415 and was buried in the monastery of Odivelas before the nuns' choir on the nineteenth day of the same month. ${ }^{30}$ On the ninth of October the following year her precious body was disinterred, having been found to be intact and pleasantly sweet-smelling ${ }^{31}$ by the most victorious King Dom João, her husband and the most illustrious princes, namely: Dom Duarte her ftrstborn, ${ }^{32}$ and Dom Pedro, Duke of Coimbra, ${ }^{33}$ and Dom Henrique Duke of Viseu, ${ }^{34}$ and Dom João, ${ }^{35}$ and Dom Fernando, ${ }^{36}$ and the Princess Dona Isabella, ${ }^{37}$ children of this most glorious King and most favourable Queen. With an abundant number of prelates, and clerics and monks accompanying and with such a great number of lords and noble ladies and ladies in waiting in attendance, the body of the aforesaid Queen was carried with the greatest honour to this Monastery of Victory, ${ }^{38}$ and buried in the major and principal chapel ${ }^{39}$ on the ftfteenth day of October in the year of our Lord 1416. Afterwards she was translated to this Chapel, ${ }^{40}$ and concealed in this tomb with the body of the most glorious King Dom João, her most virtuous spouse, beneath that form which is enclosed/preserved within his epitaph. ${ }^{41}$ May all-powerful God deign to glorify their persons with eternal joy. Amen.

North side: João's epitaph

In the name of God. Amen.

Most serene and never defeated Prince, and most victorious and noble, resplendent with virtues, Dom João the tenth king of Portugal, sixth king of the Algarve: ${ }^{42}$ and the ftrst man among Christians to be the most powerful lord of Ceuta in Africa after the general destruction of Spain, is buried in the present tomb.

This most excellent King was born in the most noble and faithful city of Lisbon in the year of our Lord 1358, and was knighted in that same city by his father the most serene Dom Pedro when he was ftfteen years old. ${ }^{43}$ Following the death of his brother King Fernando ${ }^{44}$ he ascended to the governance of the city of Lisbon and of many other fortresses, which subjected themselves to him. With the city of Lisbon having been besieged for nine months by sea by a very large fleet belonging to the King of Castile, ${ }^{45}$ and the territory fenced in by a huge army, and the forces surrounded by many of the King of Castile's Portuguese reinforcements, ${ }^{46}$ he personally defended that city of Lisbon most strenuously from cruel enemies and many assaults. ${ }^{47}$

Then in the year of our Lord 1385, having been most joyously raised to kingship in the noble city of Coimbra, ${ }^{48}$ he carried out a wondrous series of wars by himself and along with his noble warriors. By frequently invading the dominions and lands of his adversaries he, most glorious, triumphed: and he 
gained an extraordinary and royal victory around this monastery: where this most invincible King, by the strength of Omnipotent God, most powerfully vanquished Don Juan, King of Castile, who was strengthened by a great force of his own soldiers, and supported by the reinforcements of many Portuguese and those of other foreign nationalities. ${ }^{49}$ How many fortiftcations of this Kingdom and military camps - now reduced by the power of enemies - did he reconquer by the strength of his arms, protecting them most virtuously until the end of his life! And crediting this most powerful victory, which he obtained in the month of August on the vigil of the Assumption, ${ }^{50}$ to God and the most glorious Virgin Mary Our Lady, he ordered this monastery to be built in praise of them, more beautiful and unique than any other in Spain. ${ }^{51}$ Both wishing glory and honour to be given to God alone, and the greatness to be identifted only with Him, or rather, on account of him, he decreed that the description [i.e. record], which was recorded in the time of his predecessors in the public records from the year of Caesar, should be annotated from then on according to the year of our Lord Jesus Christ. This took place in the year of Caesar 1460 and in the year of the Lord 1422, with time recorded differently.52

This most blessed King, discovering that the kingdom which he had acquired had been subjected to forbidden customs no less than to savage enemies, purged these things with salutary diligence, and uprooting with his own acts of virtue the habitual crimes, he caused upright honesty to spread forth in these Kingdoms. Concerned that peace be embraced amongst Christians, he obtained perpetual peace before his own death, for himself and his successors.

And inflamed with the fervour of faith, this most Christian King sailed across to Africa, accompanied by the most serene Infante Dom Duarte his ftrstborn son and heir, and Infante Dom Pedro, and Infante Dom Henrique, and Dom Afonso Count of Barcelos, ${ }^{53}$ sons of the aforesaid King. United by a great fearlessness and might from their birth, they sailed across with a great fleet supported by more than 220 vessels, of which the greatest part were large ships and great galleys. On the ftrst day that he pressed the soles of his feet upon the ground of Africa, he wondrously drove back in his power the renowned and heavily fortifted city of Ceuta with ftghting, ${ }^{54}$ and afterwards, besieged in the same city by more than 100,000 Arab soldiers (so it is said) from across the sea and soldiers from Granada, the same most glorious King sent for aid by means of his illustrious children, Infante Dom Henrique, and Infante Dom João and Dom Afonso Count of Barcelos, and other lords and nobles: ${ }^{55}$ lords who, putting so many Arabs to flight from the siege by cutting them to pieces by the edge of the sword; with their fleet dashed to pieces by sinking, ftre and capture: he liberated the aforesaid city of Ceuta, which, after eighteen years minus eight days in the year of our Lord 1433 in the month of August on the vigil of the Assumption of the most blessed Virgin Mary, having been attacked he defended most valiantly against the multiple armies of the Arabs. ${ }^{56}$ On the aforesaid month and vigil this most glorious King joyfully completed his mortal life in the city of Lisbon, ${ }^{57}$ with his sons standing by and many other nobles, leaving the famous city of Ceuta under the governance of the most high and powerful Dom Duarte his 
son, who, manfully imitating his father's deeds, strives to govern the same city favourably in the faith of Jesus Christ. ${ }^{58}$

This most excellent and virtuous King Dom Duarte most honourably carried the body of his father the most Christian King, ${ }^{59}$ assisted by his own brothers: ${ }^{60}$ Infante Dom Pedro Duke of Coimbra and Lord of Montemor-o-Velho, ${ }^{61}$ Infante Dom Henrique Duke of Viseu and Lord of Covilhã, and Grand Master of the Order of Christ; ${ }^{62}$ Infante Dom João Constable of Portugal, and Grand Master of the Order of Saint James; ${ }^{63}$ and Infante Dom Fernando, and Dom Afonso, Count of Barcelos, sons of the aforesaid King Dom João, who did not have other children at the time of his death, ${ }^{64}$ besides two daughters, one of which was Infanta Dona ElizabethDuchess of Burgundy and Countess of Flanders, and of other duchies and counties: and the other was Dona Beatrice Countess of Huntingdon and Arundel, ${ }^{65}$ who remained in their lands. However, the aforesaid King, Dom João had grandchildren who were present at the lord's translation: ${ }^{66}$ Dom Afonso Count of Ourem, and Dom Fernando Count of Arraiolos, sons of the Count of Barcelos: and he had a grandson Dom Infante Afonso, ftrstborn of Dom Duarte, ${ }^{67}$ and other grandchildren, and great-grandsons who numbered twenty with the sons, at the time when he departed from the present world to God. Indeed, all those who were then prelates in the cathedral churches of this Kingdom were present at the ceremony of this translation, and many others with an abundant multitude of clerics and monks: and the lords and nobles of this land, even the prominent administrators ${ }^{68}$ of cities and fortiftcations were present. ${ }^{69} \mathrm{His}$ royal body was carried with great reverence to this monastery on the thirtieth day of November in the aforesaid year of our Lord, and buried in the principal chapel ${ }^{70}$ with the most excellent and noble, and most Christian Dona Philippa his only wife, mother of the aforesaid King Duarte and the princes and most illustrious Duchess. In the following year on the fourteenth of August, ${ }^{71}$ the aforesaid bodies of the aforesaid King João and Queen Philippa were carried with singular honour by King Duarte and the princes and counts to this Chapel, which he had ordered to be built for their burial. ${ }^{72}$ For this procession there was present ftrst, the highest and most excellent Dona Leanor Queen of these Kingdoms, ${ }^{73}$ and Infanta Dona Isabella Duchess of Coimbra, ${ }^{74}$ and Infanta Dona Isabella wife of the Infante Dom João, ${ }^{75}$ and the most eminent and powerful part of the prelates, lords and nobles of this land, who attended the burials of the aforesaid King and Queen, on whom may God in His mercy and piety deem worthy to bestow joy without end. Amen.

Notes

The transcription is designed to be a map for the visual appearance of the epitaph, as well as a record of the text itself.

- The layout and paragraphs in the inscribed epitaphs have been retained.

- Underlined words indicate recarving.

- Large bold letters indicate decorated capitals.

- Words in bold are visible on the monument, but not included in the earlier transcriptions by de Sousa or S. Luíz. 
1. The ftrst half of Philippa's epitaph, down to 'Haec felicissima Regina', is not included in Luís de Sousa's 1623 transcription and Portuguese translation, nor in the Portuguese translation by José Neves in 1891 . The only transcription I have found of this section was published by Fr Francisco de S. Luiz in 1827 who claimed he was copying an earlier (and apparently unpublished) transcription by Joseph Soares da Silva, the author of Memórias para a historia de Portugal que comprehendem o governo del rey $D$. Jõ̃o O I, Lisbon, 1732

2. The abbreviation could also be 'rer' (' $r$ ' with a stroke through it) which would give 'mutarerit' or 'mutare it', but these alternatives make less sense as the other verbs are in the perfect tense.

3. This section of the inscription is badly damaged, although it also seems that some of the words may never have been carved. Luiz has only 'Branche... domini Petri', but I have added 'mut[av]itcu[m]l ...', also visible on the stone.

4. This part of the stone is extremely abraded, meaning that my transcription relies heavily on the one made in 1827 by Fr Francisco de S. Luíz. However, there are a number of oddities in his transcription of this sentence that may indicate hat the damage had already occurred by this date, forcing $S$. Luíz to make an educated guess for some of the endings of the words. Oddities include the phrase 'bellicos multiplicatos', 'insultus' rather than 'insultis' and 'praesidiavit', which may instead be 'praesedit'.

5. Philippa of Lancaster (1360-1415).

6. Philippa's grandparents were Edward III, King of England (1312-77, reigned 1327-77) and Philippa of Hainault (1310/15?-1369).

7. Henry IV, King of England (1367-1413, reigned 1399-1413). The reference to them being siblings 'from both parents' relates to the fac that Philippa had ftve half-siblings, the offspring of her father's second and third marriages. Henry was her only full brother; she also had one full sister, Elizabeth of Lancaster (1364?-1425).

8. John of Gaunt, Duke of Lancaster and self-styled King of Castile and Léon (1340-99), was the fourth son of Edward III and Philippa of Hainault.

9. Blanche of Lancaster (1346?-68) married John of Gaunt in May 1359. After the death of her father, Henry of Lancaster, and sister Maud, duchess of Zeeland, Blanche inherited the entire Lancastrian inheritance, making her husband John the richest nobleman in England with a gross income of $\mathrm{c}$. $£ 12,000$ per annum.

10. Blanche's early death on 12
September 1362 was widely mourned. In his will of 1398 John of Gaunt asked to be buried alongside Blanche, suggesting that, even after two subsequent marriages, she still held a particular place in his affections.

11. Although this section of the inscription is damaged and/or was left uncarved, it is clear from the rest of the sentence that the missing words must have been a reference to Gaunt's second wife, Constanza of Castile (1354-94), whom he married inSeptember 1371 .

12. Pedro I, King of Castile, known as 'the Cruel' (1334-69, reigned 1350-69), was one of the most controversial kings of the Castilian Middle Ages. Pedro was deposed and murdered by his half-brother Enrique de Trastámara during the Castilian civil war of 1366-69. Constanza was the second daughter of Pedro and Mária de Padilla, whom after her death Pedro claimed to have married, thus legitimating their four children.

13. 'This' being his marriage to Constanza of Castile.

14. A literal translation of the Latin would be: 'with the power/ force of the peoples of the English dominions' or 'with the power of the dominions of the English people(s)'.

15. João I, King of Portugal (1357-1433, reigned 1385-1433)

16. John of Gaunt sailed from Plymouth to La Coruña in Galicia in July 1386 with an army of approximately 5,000 men. The duke and his army brought the rest of Galicia under their control before establishing themselves at Orense for the winter.

17. Praelibatum, translated here as 'aforesaid', literally means 'examined or inspected'. This seems to refer to the fact that Philippa's character and family were 'examined' in the ftrst paragraph.

18. The marriage of Philippa of Lancaster to João of Portugal sealed the Anglo-Portuguese alliance of November 1386. In return for Philippa's hand in marriage, João promised to contribute 5,000 men to the duke's war effort. A marriage alliance may have been intended from the start as John of Gaunt took Philippa to Iberia as part of his expedition to claim the Castilian throne.

19. A joint Anglo-Portuguese army invaded León in March 1387. Although the epitaph presents this campaign as a success, in reality the army was forced to withdraw within six weeks.

20. Juan I, King of Castile (1358-90 reigned 1379-90). The treaty between Juan I and John of Gaunt was agreed at Trancoso in July 1387.

21. Enrique III, later King of Castile, known as 'the Sufferer' 1379-1406, reigned 1390-1406).

22. Catherine of Lancaster was the only surviving child of John of Gaunt and Constanza of Castile. Her mother was the daughter of Pedro I, King of Castile. Shemarried Enriquein 1387.

23. The dobla was an Almohad gold piece, used in many Iberian kingdoms and regularly minted in Castile from the ftrst half of the fourteenth century. Six Castilian doblas were worth approximately one English pound.

24. The Latin word used is 'procuratores', which can mean various types of prominent administrative agents.

25. In the Latin, 'universos' is accusative, not nominative. This could well be an error on the part of the composer or sculptor as otherwise the sentence does not make sense.

26. The Divine Offices, or Liturgy of the Hours, is a daily cycle of prayer consisting mostly of Psalms, which marked particular hours of the day. Originally developed for monastic orders, by the later Middle Ages the Divine Offices were also followed by many laypeople.

27. Philippa introduced the Sarum Rite, the form of services followed by most churches in England, to Lisbon Cathedral.

28. In the ftfteenth century there was much emphasis on the value of a good death, as seen in the popularity of Ars moriendi (art of dying) instruction manuals.

29. The Last Rites, consisting of Extreme Unction, Confession and Mass.

30. São Dinis de Odivelas, located just outside Lisbon, is a female Cistercian monastery founded by Dinis, King of Portugal (1261-1325), who was also buried between the choir and chancel. Philippa had taken refuge in the palace at Odivelas on 5 July in an attempt to escape the plague ravaging Lisbon and Sacavém.

31. The description of a corpse as 'integrum inventum et suaviter odoriferum' was a typical way to indicate sainthood in the Middle Ages.

2. Duarte I, later King of Portugal (1391-1438, reigned 1433-38).

33. Pedro (1392-1449), regent of Portugal from 1440-46, a well-educated prince with humanist leanings who supported Henrique's plans for maritime expansion.

34. Henrique, known as 'the Navigator' (1394-1460), a renowned chivalric prince and patron of the colonization of Madeira and the Azores.

35. João, later Constableo of Portugal (1400-42).

36. Fernando, known as 'the Holy Prince' (1402-43). Fernando was handed over to the Marinid rulers of Morrocco in 1437 as a hostage for the return of Ceuta; he died in custody in Fez in 1443 . Although not officially

canonized, he was revered as a saint in Portugal after his death.

37. Isabella of Portugal (1397-1471) was Duchess of Burgundy as the third wife of Philip the Good, Duke of Burgundy (1396-1467). She bore Philip a son and heir to the duchy of Burgundy, Charles the Bold (1433-77).

38. The monastery of Batalha was dedicated to St Mary of Victory.

39. 'Capella majori et principaliori' suggests that the queen's body was buried in the central apsidal chapel of the monastery church. However the presence of an epitaph on the west wall of the south transept, along with the recentdiscovery of a cavity under the pavement of the southernmost apsidal chapel, indicates that Philippa was interred here instead. Thanks to Pedro Redol for supplying this information.

40. A reference to the Founder's Chapel, situated at the west end of the monastery church, in which the monument and this inscribed epitaph stand (see note 72 below)

41. The ceremony of translation to the Founder's Chapel is described in detail in João's epitaph below. The chronology of the epitaphs, and this note, indicate that they were designed to be read as a pair, starting with Philippa's and ending with João's

42. The Algarve was a nominal kingdom within the kingdom of Portugal.

43. Pedro I, King of Portugal, known as 'the Just' or 'the Cruel' (1320-67, reigned 1357-67). João was Pedro's illegitimate son, born to his mistress Teresa Lourenço.

44. Fernando I, King of Portugal (1345-83, reigned 1367-83). Fernando was actually a half-brother to João, as he was a legitimate son, with his mother being Pedro's ftrst wife Queen Constanza Manuel. The death of Fernando created a crisis of succession as his only child, a daughter, was married to Juan I, King of Castile, raising the possibility of a Castilian king on the Portuguese throne.

45. Juan I, King of Castile (see note 20 above)

46. Juan I of Castile invaded on the appeal of Queen Leonor, Fernando's widow, and was supported by many in the Portuguese nobility.

47. This account is notable for the absence of any reference to Nuno' Alvares Pereira, a knight and brilliant strategist, whose military 
defence of the realm proved he deserved to be king.

49. The Battle of Aljubarrotta took place on 14 August 1385. Despite the fact that Juan of Castile was supported by an army of 22,000 men, outnumbering João by more than three to one, he suffered a crushing defeat. This was the decisive battle in the political struggle for the Kingdom of Portugal, putting an end to Juan I of Castile's claim to the throne and leading to the slaughter or exile of the Portuguese magnates who had supported him.

50. The vigil (i.e. the day before) of the feast of the Assumption of the Virgin Mary is 14 August.

51. In his will of October 1426, João describes how he had ordered the monastery of Batalha to be built on the site of the battle of Aljubarrota in gratitude to the Virgin for his victory granted by God. This monastery was the major artistic project of João's reign, with construction beginning at the time of the siege of Melgaço in 1387 continuing throughout the rest of his life.

52. This refers to a decree issued by João I on 22 August 1422, ordering all royal and private documents to be dated according to the Christian era (Lisbon, Arquivo Nacional Torre do Tombo, Chanc. Régias, 23, fol. 132v). Thanks to Filipe Alves Moreira for alerting me to this document.

53. Afonso, Count of Barcelos, later Duke of Braganza (c. 1380-1461) was the illegitimate son of João I and Inês Pires, legitimized by his father on 20 October 1391.

54. The Portuguese conquest of Ceuta, held by the Marinid dynasty, was carried out in a single day on 21 August 1415 after an assault lasting thirteen hours.

55. By 1418 the Marinids had regrouped their armies and, with help from the Nasrid rulers of Granada, besieged the Portuguese forces in Ceuta, forcing João to send for a relief expedition.

56. In reality, the wars between Portugual and the Marīnids continued after João's death, most notably in Portugal's unsuccessful attempt to capture Tangiers in 1437. The defeated Portuguese army was forced to sign a treaty promising to hand Ceuta back to the Marinids, although this promise was never fulftlled. The artiftcial end-date to the wars over Ceuta is part of an effort to link João as closely as possible to the feast of the vigil of the Assumption of the Virgin Mary, the date of his most prominent military victory at Aljubarrotta. See note 49 above.

57. i.e. 14 August 1433.

58. The use of present tense 'nititur' indicates that the epitaphs were composed during the reign of Duarte I, and most likely ordered by the king himself.

59. Other sources indicate that Duarte took a leading role in his parents' funeral ceremony. The new king even wrote a sermon for the occasion, the outline of which has survived. See A. J. Dias Dinis, Esquema de sermão de el-rei D. Duarte para as exéquias de D. João I, seu pai, Braga, 1954.

60. The Latin word used here is 'germanis', which literally means 'own' or 'full' brothers. This is an interesting choice of word given that one of the men listed (Afonso, count of Barcellos) was only a half-brother to Duarte.

61. The differences between the titles of the royal children recited here and those in Philippa's epitaph reflect the honours that they had amassed between her death in 1415 and that of João in 1433.
62. The Order of Christ was the former Order of the Knights Templa (a Christian military organization) as it was reconstituted in Portugal after the dissolution of the Templars in 1312.

63. The Order of St James of the Sword was another prominent Christian military organization, originally founded to protect pilgrims travelling to the shrine of St James in Santiago de Compostela.

64. João and Philippa had at least two children who predeceased them both: a daughter, Branca, and their ftrst-born son, Afonso, who died in 1400. Afonso is commemorated by a magniftcent gilt cast-copper alloy effigy with silvered details in Braga Cathedral.

65. Beatrice, Countess of Huntingdon and Arundel (c. 1386-1439), was the illegitimate daughter of João and Inês Pires. She married Thomas Fitzalan, Earl of Arundel, in 1405 in a ceremony attended by Henry IV. Following his death, she remarried John Holland, Earl of Huntingdon, in 1433. She is buried in an alabaster tomb alongside Thomas Fitzalan in the Fitzalan Chapel, Arundel Castle, West Sussex.

66. 'Dominicus' when used as an adjective usually refers to the Lord (Jesus) or Sunday, the Lord's day. This is a play on words, relating the body of the king to that of Christ.

67. Later Afonso V, King of Portugal (1432-81, reigned 1438-81). He acceded to the throne aged six; his long minority was overseen by his uncle Pedro as regent.

68. The Latin word used is 'procuratores'. See note 24 above.

69. A literal translation of 'extitere praesentes' would be 'presently stood forth', with connotations of a ceremonial occasion or procession.
70. For the original burial location of the king and queen, see note 39 above.

71. 14 August is the vigil of the Assumption of the Virgin, the date of the Battle of Aljubarrotta and thus a feast of particular signiftcance to João.

72. João ordered the construction of the Founder's Chapel in his will of 1426 , ordering that he should be buried there in a joint memorial - a novelty in Portugal - with Philippa, his late wife. He also forbade anyone except the king of Portugal to be buried in the centre of the chapel, and restricted tombs in the chapel walls to the sons and grandsons of kings.

73. Leonor of Aragón (d. 1445), later Queen of Portugal, married Duarte on 22 September 1428 . The couple had ten children, including the future Afonso V. Duarte appointed Leonor as regent during Afonso's minority but she lacked the consent of the Cortes (parliament) and was forced to flee back to her relatives in Castile. She is commemorated in the Unftnished Chapel at Batalha with a memorial showing her effigy holding hands with that of her husband.

74. Isabella of Urgell, Duchess of Coimbra (d. 1459), was the daughter of Jaume II, Count of Urgell (Aragón). In 1422 she married Pedro, Duke of Coimbra, with whom she had six children. She is buried in the Founder's Chapel alongside her husband.

75. Isabella of Barcelos (d. 1465) was the daughter of João's illegitimate son, Afonso, Count of Barcelos, and his wife Beatriz Pereira de Alvim. She married her half-uncle João, Constable of Portugal, and is buried alongside him in the Founder's Chapel. 



\section{Jessica Barker in conversation with Joana Ramôa Melo and PedroRedol}

Jessica Barker: Could you speak about the exhibition you curated at Batalha in 2015, Places of Prayer in the Monastery of Batalha?

Pedro Redol: The intention of this project was to try to understand, and in some way compensate for, the exaggerated weight on nationalistic symbolism, to try to go back to the main way in which this religious house worked in the past. The monastery ceased to be a religious house in 1834, when all religious houses in Portugal, especially male religious houses, ceased to exist by law. Batalha found a new status as a national institution because it is a symbol of Portuguese independence in the 1385 battle [of Aljubarrotta] against the Castilian troops. So the monastery was rehabilitated, given an additional importance in this aspect, only a few years after the extinction of the religious community. For this reason it was also the ftrst big restoration of a Gothic monument in Portugal, starting in late 1840 and early 1841. This status as national memorial was reinforced in the twentieth century, under the period of the dictatorship of António de Oliveira Salazar, and even before when the memorial to the Unknown Soldier was installed. There are various memorials in different Portuguese towns and villages but the main one - the most important one - was installed in Batalha in 1921 after the First World War. So this is how the monastery came down to us. The idea of Batalha as a place of prayer and worship is something of much more recent rediscovery, a matter which hasn't been investigated until very recently.

JB: And the exhibition Places of Prayer brought together objects, or records of objects that used to be in the monastery.

PR: Yes. Much has disappeared and part of the labour in preparing that exhibition and the catalogue was trying to understand what the whole monastery was, including what has disappeared. Some objects are still missing; for example at the MNAA [Museu Nacional de Arte Antiga] in Lisbon there are parts of altarpieces and other objects from altars in the Founder's Chapel.

Joana Ramôa Melo: I think the general public isn't really aware of what the Founder's Chapel and the tomb of João and Philippa were meant to be in their original contexts. There was a strong process of secularization of the entire structure throughout the nineteenth century, especially from the dissolution of the religious orders onwards. This was a moment in which the appearance of the chapel and the tomb was fundamentally changed. I believe that this is the main value and signiftcance that has lasted for the general public - the political dimension of the chapel, the idea of a place where a new dynasty is commemorated. This is seen in the very designation of that building as a 'Founder's Chapel', which is not original to its construction but rather a 
contemporary label which reflects the political and patriotic perception of this structure. People aren't aware of all the lost items of the chapel.

The latest academic studies have tried to focus particularly on highlighting the original conception of the chapel, its relation to all these other artistic items, and all these other meanings that have been lost with these items. The exhibition and catalogue for Places of Prayer reflected that intention to get people closer, more aware of the religious and spiritual nature of Batalha which, after all, is a monastery, and not just part of a historic monument.

It is very interesting that the publication linked to the restoration process, which was published in the middle of the nineteenth century by Mouzinho de Albuquerque, avoids the word 'monastery' and focuses instead on the word 'monument'. This seems like a subtle distinction but it is a culturally charged choice that has deeply marked the contemporary perception of Batalha. It is now seen as a monument, not a monastery.

JB: Could you say something about the project, 'Monumental Polychromy: Revealing Medieval Colours at Batalha', which you are leading on the technical analysis of the wall paintings in the Founder's Chapel? How does that $\mathrm{ftt}$ into current research?

JRM: It ftts exactly into the perspective I was mentioning. When we talk about the loss of the chapel's original environment we are not only talking about retables and liturgical objects, we are also speaking about colour, which was a main element in the political, familial and religious signiftcance of the structure. We want to know to what extent colour was used as an instrument to convey speciftc messages, and to what extent these messages were complementary to those conveyed by the sculpture and architecture, or if colour could create other messages that would obviously dialogue with the messages of the sculpture and architecture. We have already taken samples from the tomb of João and Philippa, but also from some of the architectural structures and the princes' monuments and they are being studied by the chemistry team. They haven't ftnished that study, but they have already told us something about the results. We now know, for example, that the tomb of the royal couple was really a much more striking piece full of very intense colours, such as red, black and gold.

I think that academic research has to project its ftndings and novelties to a more general public. Because you will only value - really value - that structure for what it was and not what the nineteenth and early twentieth centuries have told you it was, if you are aware of all these aspects that can be shown by academic research. A key aspect of all research should always be to relate to the wider community. The research we are doing has to reflect a change in the visitor's experience of that same structure.

That's why our project intends to produce a device that will allow visitors to have a virtual visit to the chapel with its original colours. We are thinking about developing an app, which will be possible to download to your mobile phone or tablet. Or you will be able to access the app using a screen at the entrance to the chapel. This will allow you to see the results of our research 
as they happen. It was always a key concern of our project to create a communication channel between the research done in universities but also in Batalha itself and the change in the experience the visitor would have in visiting that structure and having a notion of what it really was.

JB: Pedro, how you see your role as curator in the context of all the different historical moments that have shaped this structure? How do you communicate the complex story of Batalha to people coming to the monastery today?

PR: Well, through very basic tools, like audio guides and some more elaborate tools which have to be accessible, so are never too complicated but sometimes very rich in information. For example, the most recent exhibition, Places of Prayer in the Monastery of Batalha.

But this is an unending story because you are always discovering new things, and you also have a story which is not only conftned to the Middle Ages, you skip to the nineteenth century, and then back again to the seventeenth, and I ftnd the task of conveying something to the visitors of Batalha too much for a single person. And in fact, I don't do this work, this effort of communication, all alone. When we have to plan and design exhibitions, or other resources, we now have a project for accessible communication for people who are partially sighted or deaf, or for people who have little experience of cultural history and do not have the tools to interpret certain aspects. This is something that we then work on by building up teams with our central services in Lisbon, because the monastery in Batalha falls under the jurisdiction of the director general for cultural heritage in Lisbon [Direção Geral do Património Cultural]. There we ftnd the necessary skills, for example, people who are skilled in communication, or architects and designers, or we then hire external collaborators if we don't have it in-house. And that is the most important and most interesting part of my job. I think the problem everyone has, you yourself I'm sure, is to ftnd the balance between research and practice. Being effective and not incompetent! Well, it's difficult, because you have to spend a lot of time to ftnd the best ways to communicate and also the means to provide communication, which costs money. And on the other hand you have to carry on research and also try and set up a sort of conversation between the knowledge provided by different scholars. That was one of the things I was trying to do this year, but our tradition in southern Europe is to improvise a lot, so we tend to plan every year, or two years, what we are going to do, and then we never do that properly!

One of the problems today - and now we are getting to the problems - is that everyone wishes to have a balance between research and practice. But in the present, we all, in Europe and perhaps all over the world, tend to give greater importance to what is apparent and representative, that which you can show somewhere, rather than what is laboured over for years somewhere in the library. But you also need this invisible work! Because otherwise we will lose our competence. Because you can't build communication on 
non-knowledge. You can't do that. For example, I think that the experience of Places of Prayer was very interesting, because there was a lot of research which had not been undertaken before, and so as we had to write this investigation, we wrote a catalogue. And then we used this academic research to write accessible texts for the general public. And this was, I think, a serious and intellectually honest exercise. 